\title{
Effects of grazing intensity on forage nutritive value of dominant grass species in Borana rangelands of Southern Ethiopia
}

\author{
Yeneayehu Fenetahun $^{1,2}$, You Yuan ${ }^{1}$, Tihunie Fentahun ${ }^{3}$, Xu Xinwen $^{1}$, Wang Yong-dong ${ }^{\text {Corresp. } 1}$ \\ ${ }^{1}$ National Engineering Technology Research Center for Desert-Oasis Ecological Construction, Xinjiang Institute of Ecology and Geography, Chinese \\ Academy of Sciences, 818 South Beijing Road, Urumqi 830011, China, Urumqi, China \\ 2 University of China Academy of Sciences, Beijing, 100049, China, Urumqi, China \\ Collage of Natural and Computational Sciences, Mekdela Amba University, Tulu Awliya, 32, Ethiopia, Tulu Awuliya, Ethiopia \\ Corresponding Author: Wang Yong-dong \\ Email address: wangyd@ms.xjb.ac.cn
}

Background. Forage nutritive value analysis is an essential indicator of rangeland status regarding degradation and livestock nutrient demand. Thus, it is used to maintain healthy and sustainable rangelands that can provide the livestock with sufficient quantity and quality of forage. This study is conducted with the aim of investigating the effects of grazing intensity combined with seasonal variation on the nutritive values of dominant grass species in the Teltele rangeland.

Methods. The studied area is classified into no-grazed, moderately grazed, and overgrazed plots based on the estimated potential carrying capacity. Sampling data is collected during both rainy and dry seasons. The collected forage samples are analyzed for concentrations of crude protein (CP), acid detergent organic fiber (ADF), neutral detergent fiber (NDF), acid detergent lignin (ADL), ash, dry matter digestibility (DMD), potential dry matter intake (DMI), and relative feed/forage value (RFV).

Results. The results show significant $(P<0.05)$ effects of both grazing intensity and season to grazing intensity interactions on all forage nutrient content concentrations across all grass species both within and between treatments. The recorded CP concentrations of all grass species are high in the overgrazed site and low at the no-grazed site, while the fiber concentration is high in NG and low in OG. RFV data also varies greatly, with high value recorded in OG in the rainy season and low value found in NG mainly during the dry season. As a result, it is recommended that moderate grazing should be practiced on the study site to maintain the quality and quantity of forage and to manage it in a sustainable manner. 


\section{Effects of grazing intensity on forage nutritive value of dominant grass species in Borana} rangelands of Southern Ethiopia

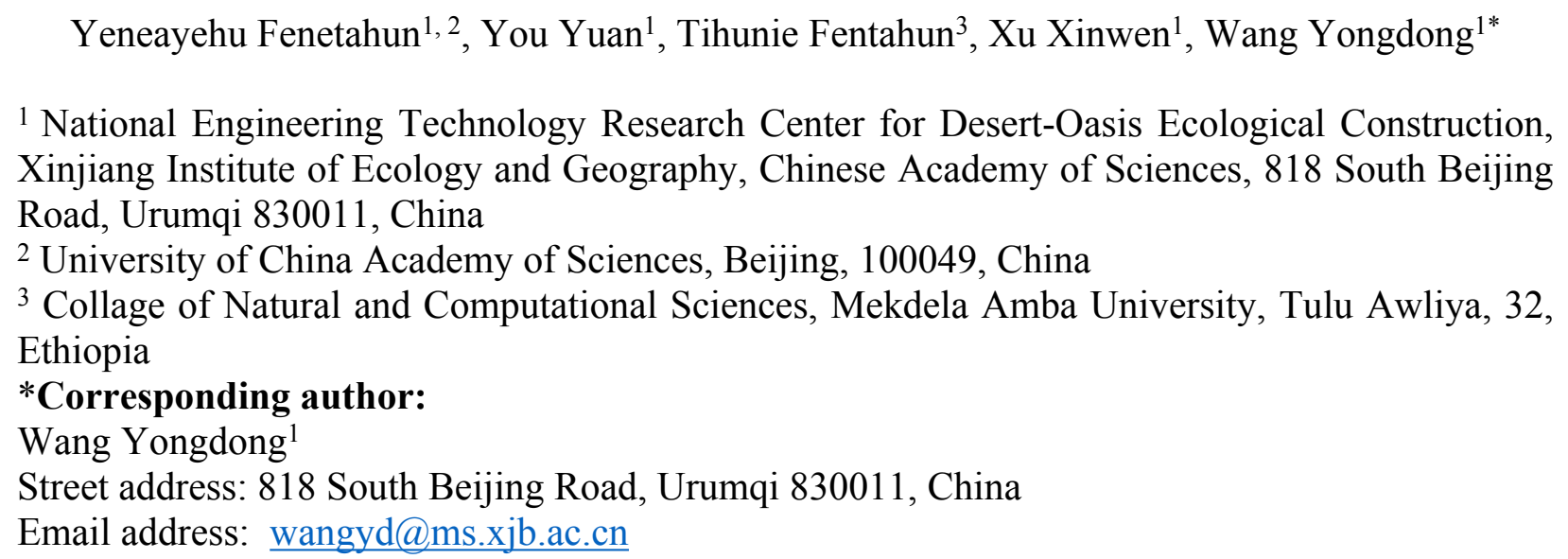

Background. Forage nutritive value analysis is an essential indicator of rangeland status regarding degradation and livestock nutrient demand. Thus, it is used to maintain healthy and sustainable rangelands that can provide the livestock with sufficient quantity and quality of forage. This study is conducted with the aim of investigating the effects of grazing intensity combined with seasonal variation on the nutritive values of dominant grass species in the Teltele rangeland.

Methods. The studied area is classified into no-grazed, moderately grazed, and overgrazed plots based on the estimated potential carrying capacity. Sampling data is collected during both rainy and dry seasons. The collected forage samples are analyzed for concentrations of crude protein $(\mathrm{CP})$, acid detergent organic fiber (ADF), neutral detergent fiber (NDF), acid detergent lignin (ADL), ash, dry matter digestibility (DMD), potential dry matter intake (DMI), and relative feed/forage value (RFV).

Results. The results show significant $(\mathrm{P}<0.05)$ effects of both grazing intensity and season to grazing intensity interactions on all forage nutrient content concentrations across all grass species both within and between treatments. The recorded CP concentrations of all grass species are high in the overgrazed site and low at the no-grazed site, while the fiber concentration is high in NG and low in OG. RFV data also varies greatly, with high value recorded in OG in the rainy season and low value found in NG mainly during the dry season. As a result, it is recommended that moderate grazing should be practiced on the study site to maintain the quality and quantity of forage and to manage it in a sustainable manner.

\section{INTRODUCTION}


Rangelands are the primary and cheapest source of forage for livestock (Ismail et al., 2014). In most countries, including Ethiopia, the livestock industry largely relies on natural rangelands, such as the Teltele rangeland (Adnew et al., 2018). Livestock depending on such natural rangelands face highly fluctuating nutritive value of forage grass species, although there is a wide array of grass species (Gelayenew et al., 2016; Newman et al., 2009; Vendramini, 2010). The nutritive value of rangeland forages varies due to influencing factors like grazing intensity, soil type, water availability, maturity/stage of development, part of the plant (leaf vs. stem), season (rainy vs. dry), environmental factors (moisture and temperature), altitude and management practice (Amiri \& Mohamed, 2012; Henkin et al., 2011; Jank et al., 2014; Kaplan et al., 2014; Adesogan et al., 2011). The nutritive value of rangeland forage is often evaluated to estimate the carrying capacity of the rangeland and assess animal performance (Godari et al., 2013). The selection of grass species for forage depends on the acceptability nature of grass, which is linked to the flavor (like smell, taste, and texture) and nutritive value of the forage (Estell et al., 2014). However, based on the density of acceptable forage species, it is impossible to estimate the nutrition quality of the forage in the grazing area (Samuels et al., 2015).

The productivity and health of grazing livestock mainly depend on the nutrition they obtain from grass species, including protein, fiber, and mineral elements (Brisibe et al., 2009; Massey et al., 2007). Therefore, key aspects to consider when evaluating forages include protein, fiber and mineral nutrient concentrations (Juárez et al., 2013). In the Teltele rangeland, the livestock population increases overwhelmingly and causes overgrazing. Year-round grazing without any rest later results in significant changes in both the productivity and forage nutritive value of the grass species (Selemani et al., 2013). If grazing intensity (GI) increases, there will be a decrease in neutral detergent fiber (NDF), acid detergent fiber (ADF) and lignin, and an increase in crude protein (CP) and dry matter digestibility (DMD) (Cline et al., 2009; Smart et al., 2010). Derner, (2009) and Njidda, Olatunji \& Raji (2012) reported that with increased stocking rate or grazing pressure, there is a decline in animal performance. The forage nutritional value shows a linear decrease in $\mathrm{N}$ and $\mathrm{CP}$ and a linear increase in NDF when it switches from rainy to dry seasons, since digestibility has decreased due to the declining leaf-to-steam ratio caused by high temperature (Kirch et al., 2003).

In the Teltele rangeland, local pastoralists share the communal grazing areas for grazing livestock year-round without rest. However, in the communal grazing areas, livestock overgrazes palatable 
67 grass species and causes rangeland degradation (Asmare et al., 2017). Changes in the forage nutritive value of communal rangeland areas have become a focus for many academicians when identifying the linkage between grazing intensity and forage nutritive value (Schut et al., 2010). Understanding these effects and managing accordingly are crucial for establishing proper grazing systems (Xiajie et al., 2018). And knowing the spatial and temporal changes in rangeland forage quality is essential for livestock farmers (Wubetie et al., 2018). Thus, estimating the influence of GI on forage quality is critical to updating knowledge for maintaining sustainable management of grasslands in Teltele. But, to date, although there are a number of studies on arid and semi-arid rangelands around the world, there is no documented study data about the impact of GI on forage nutritive value of dominant grass species in the Teltele rangeland. This is one of the major research gaps that need to be addressed for achieving substantial rangeland management through balancing grazing capacity and livestock performance.

To restore rangelands through evaluating the impact of GI on forage nutritive value, spatial methods comparable across all species within the studied site are needed to be adopted to obtain clear and measured data. This study aims to achieve the following objectives: (1) to evaluate the effect of grazing intensity on forage nutritive value of dominant grass species, and (2) to compare the nutritive values of dominant grass species during dry and rainy seasons under different grazing intensities. Accordingly, to assess and propose a solution for controlling GI within an appropriate range, the following question is put forward: How and to what extent does GI in combination with climate (seasonal) variation affect grass species productivity and nutritive value in the Teltele rangeland? Simply stated, null hypotheses proposed by this study are: (1) Variation of GI across grazing lands does not pose a significant impact on either forage nutritive value or sustainable rangeland management; (2) The primary productivity, GI, and livestock productivity are similar in both rainy and dry seasons.

\section{MATERIALS AND METHODS}

\section{Site selection}

Both site selection and data collection are done following the same procedures used previously by Fenetahun et al., (2020) in the study "Dynamics of forage and land cover changes in Teltele district of Borana rangelands, southern Ethiopia: using geospatial and field survey data". The study is conducted in the Teltele semi-arid rangeland in the Borana zone of Southern Ethiopia, by selecting 
97 areas that are no-grazed (NG), moderately grazed (MG), and overgrazed (OG) as a treatment using 98 the calculated carrying capacity of those areas for two consecutive seasons in 2019 (Fig. 1) 99 (Fenetahun et al., 2020). The study site is located between $04^{\circ} 56^{\prime} 23^{\prime \prime} \mathrm{N}$ latitude and $37^{\circ} 41^{\prime} 51^{\prime \prime} \mathrm{E}$ 100 longitude (Fenetahun et al., 2020; Dalle et al., 2015), and it is selected because it is one of the 101 most arid parts of Borana zone and, therefore, the pastoral communities of this region are the most 102 vulnerable to the rangeland degradation as a result of overgrazing (Fenetahun et al., 2020). The 103 area is located $666 \mathrm{~km}$ south of Addis Ababa, the capital city of Ethiopia (Fenetahun et al., 2020). 104 The elevation is about 496-1500 m with a maximum elevation of $2059 \mathrm{~m}$ above sea level 105 (Fenetahun et al., 2020). Rainfall is bimodal with the main (60\%) rainy season occurring between 106 March and May, while the short (27\%) rainy season occurs from September to November (Dalle 107 et al., 2015; Fenetahun et al., 2020) (Fig. 2). The two intervening dry seasons are from June to 108 August and December to February, when forage resources are scarce (Fenetahun et al., 2021; 109 Angassa, 2014). The mean annual rainfall recorded over the past 12 years (2008-2019) is 450-700 mm (NMA, 2019, and Gemedo, 2020), while the mean annual temperature varies from 28 to $33^{\circ} \mathrm{C}$ with little seasonal variation (Fenetahun et al., 2020). The annual potential evapotranspiration of the area is 700-3000 mm (Billi et al., 2015). The main soil type in the study area, composed of $53 \%$ sandy, $30 \%$ clay, and $17 \%$ silt, is mainly used to support the growth of grass species for grazing (Fenetahun et al., 2020 and 2021; Coppock, 1994; Gemedo, 2020). The rangeland vegetation is mainly dominated by encroaching woody species and those that are frequently thinned out, including Senegalia mellifera, Vachellia reficiens, and Vachellia oerfota (Coppock, 1994; Gemedo et al., 2005; Fenetahun et al., 2020). The 2015 national census reported a total population of 70,501 for this woreda, including 36,246 men and 34,255 women, and 4,874 (6.91\%) urban dwellers. At that time, cattle, goats, sheep, camel, mule, donkey, and horse were the main species of livestock species reared in the area (Fenetahun et al., 2020). Furthermore, according to data reported by the zone livestock office, the estimated total number of herds for all species is 201,148, and the proportions of each species found in the study district are: cattle 92,000 (45.7\%), goats 58,139 (28.9\%), sheep 17,210 (8.6\%), camels 15,305 (7.6\%), horses 8,000 (4.9\%), mules 3,494 (1.7\%), and donkeys 7,000 (3.5\%). For the OG site, all species graze year-round without rest, as pastoralist migration from one area to another is highly limited by government policies, which is a major cause of overgrazing and greatly impacted the nutritive value of grass species in 127 the Borana rangelands. 


\section{Experimental design and sample collection}

129 Data is collected using the same procedures described by Fenetahun et al. (2020), as the same site 130 is studied. We select the site using three treatments: a no-grazed (NG) site (as a control), a 131 moderately grazed site and an overgrazed site (used to examine the effect of grazing intensity) 132 based on grazing intensity gradient (Fenetahun et al., 2021) and the current carrying capacity 133 potential (Fenetahun et al., 2020 and 2021). Inside the NG site, livestock has been abandoned, so 134 the site is used as a reference to compare the forage nutritive value with other areas and to evaluate 135 the impact of GI. The livestock species found in all grazing treatments are the same and the only 136 variables are density and GI. Once the forage yield and utilization rate are determined, the carrying 137 capacity (CC) can be calculated. The information can be used in two alternative ways: (a) to 138 determine stocking rate or the number of heads of animals a system can carry in terms of the total 139 livestock unit (TLU ha ${ }^{-1}$ year ${ }^{-1}$ ), or (b) to determine how much area a specific herd can graze in 140 the system (ha TLU ${ }^{-1}$ year $\left.^{-1}\right)(\mathrm{FAO}, 1988)$. Similar to the CC calculation, $30 \%$ consumable rate is

$$
\text { Stocking rate for the year }\left(\mathrm{TLUha}^{-1} \text { year }^{-1}\right)=\mathrm{TLU} / \text { total }
$$

The treatment sites for sample collection involves a stocking rate of $\mathrm{NG}\left(\sim 0 \mathrm{TLU} \mathrm{ha}^{-1} \mathrm{Y}^{-1}\right), \mathrm{MG}$ (2 TLU ha ${ }^{-1} \mathrm{Y}^{-1}$ ), and OG (4 TLUha ${ }^{-1} \mathrm{Y}^{-1}$ and above) based on the current forage biomass yield and carrying capacity of rangeland calculated by applying the approach proposed by Fenetahun et al. (2020) and through physical field observation. The treatments with different GI are selected and investigated at $2 \mathrm{~km}$ intervals (Fenetahun et al., 2021). The selected rangeland sampling areas of these three GI sites are 100 ha for each (in total one $\mathrm{NG}+$ one $\mathrm{MG}+$ one OG sites $=300 \mathrm{ha}$ ) (Fenetahun et al., 2021). The sites are selected from a homogeneous area and have similar geographical conditions like slope, elevation, and soil types (Fenetahun et al., 2021). The grazing treatments and sample collection are implemented both during the dry season (from December 2018 to February 2019) and the rainy season (from March to May 2019) at the time where grass species can be easily observed and peak biomass is recorded to evaluate the interactional effect of seasonal variation combined with GI, with three replications for each season (Fenetahun et al., 2021). Then, after establishing a $5 \mathrm{~km}$ transect both in the $\mathrm{NG}$ and grazing sites, five $50 \mathrm{~m} \times 50 \mathrm{~m}$ 
159 plots each). Then, in each plot, three $5 \mathrm{~m} \times 5 \mathrm{~m}$ subplots are randomly assigned as pseudo160 replicates out of the total of 45 subplots in grazing and non-grazing treatments (Fenetahun et al., 1612020 and 2021). Finally, five $1 \mathrm{~m} \times 1 \mathrm{~m}$ quadrats in each subplot, with a total of 225 quadrats per 162 season (450 quadrats across the two sampling seasons) are assigned by randomly casting them 163 back side to minimize any bias resulting from selective placement in each subplot for the collection 164 of samples of grass species over two consecutive seasons (Fig.1) (Fenetahun et al., 2020 and 2021). 165 The total sampling of 5 plots $\times 3$ sub-plots $\times 5$ quadrats $\times 2$ seasons $\times 3$ replications $=450$ for each 166 treatment site is conducted (Fenetahun et al., 2020 and 2021). Moreover, the same sample 167 collection techniques and treatment sites are adopted during the dry and rainy seasons (Fenetahun 168 et al., 2020 and 2021). In each sampling unit, we record the dominant grass species and abundance 169 for each grass species (Fenetahun et al., 2020 and 2021). All the ground grass samples are obtained 170 by using a cutter and each grass species is stored separately in a paper bag (Fenetahun et al., 2020 171 and 2021). The fresh weight of the collected grass samples is measured in the field with a scale 172 (Fenetahun et al., 2020 and 2021). Then, the samples are oven-dried for $48 \mathrm{~h}$ at $55^{\circ} \mathrm{C}$ to value the 173 biomass. The sub samples are used to calculate the dry weight of forage mass and estimate forage 174 nutritive value as described below (Fenetahun et al., 2020 and 2021). The dried samples are first 175 measured and grounded to pass a $1 \mathrm{~mm}$ screen for further analysis at a lab of College of Agriculture 176 and Environmental Sciences, Bahir Dar University, Ethiopia. The evaluated forage comprising 177 five dominant grass species (Chloris roxburghiana, Cenchrus ciliaris, Chrysopogon aucheri, 178 Aristida kenyensis and Digitaria milanjiana) is selected and sampled based on relative abundances $179(\geq 40 \%)$ and pastoralists' experiences and preferences for certain grass species (Habtamu et al., 180 2013). Grass species are identified in the field by using identification keys, plates, the book Flora 181 of Ethiopia, and the National Herbarium of Addis Ababa University (Dalle et al., 2015). The 182 specific assessment for detailed acceptability values of dominant grass species and soil 183 physicochemical properties is given by a study carried out on the same site and by the same author 184 (Yeneayehu et al., 2020).

\section{Forage nutritive value analysis}

186 Forage samples are analyzed for multiple quality factors on a dry mass basis, with a crude protein 187 (CP), neutral detergent fiber (NDF), acid detergent fiber (ADF), acid detergent lignin (ADL), ash, 188 dry matter digestibility (DMD), potential dry matter intake (DMI), and relative feed/forage value 189 (RFV) following standard procedures as described below (Table 1). The calculated results of CP, 
190

191

192

193

194

195

196

197

198

199

200

201

202

203

204

205

206

207

208

209

210

211

212

213

214

215

216

217

218

219

220

221

$\mathrm{NDF}, \mathrm{ADF}$, and ADL are presented using $\mathrm{g} / \mathrm{kg}$ as unit and ash, DMD, RFV and DMI are expressed in the form of percentage (\%). Based on the obtained results of NDF, ADF, DMD and DMI, the forage nutritive quality of the grass species can be estimated and ranked by adopting the following formula (Fazel et al., 2012). DMI, calculated as a percentage, estimates the relative amount of forage an animal will eat when only forage is fed (Undersander et al., 1993).

$$
\begin{aligned}
& \% \mathrm{DMI}=120 / \% \mathrm{NDF} \\
& \mathrm{RFV}=\frac{\mathrm{DMD}(\%) \times \mathrm{DMI}(\%)}{1.29}
\end{aligned}
$$

$\mathrm{RFV}=$ Relative forage value of forage species predicted by NDF and ADF.

\section{Statistical analysis}

Forage nutritive value data is analyzed using SPSS Version 22 with grazing treatment and season as well as their interactions as fixed factors, and plot considered as a random factor. Plot is treated as a repeated measure. There are 450 sample observations ( 5 plots $\times 3$ sub-plots $\times 5$ quadrats $\times 2$ seasons $\times 3$ replications) in each GI site for each forage variable (CP, ADF, ADL, DMD, DMI, NDF). Analysis for repeated measures concerning forage nutritive values is performed using a mixed model (Proc Mixed), including GI (NG, MG and OG), season (dry and wet), and their interactions as repeated effects. A two-way analysis of variance (ANOVAs) followed by a Duncan's multiple range test is performed to test significant differences $(\mathrm{P}<0.05)$ between NG, $\mathrm{MG}$, and $\mathrm{OG}$ treatments within and between each season. A simple linear regression analysis is conducted to examine the relationship between GI and various variables (from forage nutritive value response ratio to grazing in each season). A principal component analysis (PCA) is carried out to examine the relationship between forage nutritive values of the species based on the experimental results.

\section{RESULTS}

\section{Effects of grazing intensity on forage nutritive value}

The relative abundances of the selected dominant grass species across all grazing intensities and seasons are presented in Fig. 3. Based on the recorded data, C. roxburghiana, C. ciliaris and $C$. aucheri are $>60 \%$, A. kenyensis is $\geq 50 \%$, and D. milanjiana is $\geq 40 \%$ in abundance both during the rainy and dry seasons. C. aucheri is the most abundant grass species in Teltele rangeland, followed by $C$. ciliaris and $C$. roxburghiana. The effects of GI on forage nutritive value varies 
222 significantly $(\mathrm{P}<0.05)$ in terms of $\mathrm{CP}, \mathrm{ADF}, \mathrm{NDF}, \mathrm{ADL}$, ash, and RFV contents both within and

223 between each species (Table 2). For all grass species, the concentrations of CP and ash increase 224 when GI rises, while the concentrations of ADF, NDF, and ADL decrease when GI drops. For the 225 dominant grass species, the effect of GI on the forage nutritive value is described using linear 226 regression analysis (Fig. 4).

227 According to the regression analysis results, the RFV of forage shows significant differences $(\mathrm{P}>$ 228 0.05) under different GIs. It presents a decreasing pattern if the concentrations of ADF, NDF, and 229 ADL value are increasing, yet shows an increasing pattern when the concentrations of CP and ash 230 value increase (Fig. 4). The RFV value could be used to estimate the forage quality. The higher 231 the RFV value is, the higher the quality is. C. roxburghiana, A. kenyensis, and C. aucheri are grass 232 species with high RFV (forage quality) based on our research data.

233 In the NG site, the concentration of $\mathrm{CP}$ for all grass species is below the minimum requirements 234 for beef cattle (7\%) with the exception of C. ciliar (7.7\%) and for small ruminants (9\%) (Gemedo, 235 2020; Habtamu et al., 2013). Across all GIs, the concentration of CP for C. roxburghiana, A. 236 kenyensis and $D$. milanjiana is below the minimum requirements for most grazing animals. This 237 is because the grass maturity at the NG site increases and results in a lower leaf-to-stem ratio, 238 leading to an increase in ADF, NDF and ADL, and a decrease in CP. At the NG site, the forage 239 quality decreases as compared with both the MG and OG, due to decreasing digestibility and 240 increasingly maturing proteins.

241 On the other hand, with an increasing GI, the rate of new growth declines, and the consumption of 242 less desirable materials, such as the remaining part of mature forages from the previous growing 243 season, results in a decreasing CP concentration. The concentrations of ADF, NDF, and ADL are

244 highest for D. milanjiana, followed by $C$. ciliary, and lowest for C. roxburghiana, followed by $A$. 245 kenyensis. The concentration shows a decreasing pattern when it switches from NG to OG and 246 presents a significant difference $(\mathrm{P}<0.05)$ both within and between species and across GIs. High 247 ash content is recorded for $C$. ciliary and low for C. roxburghiana, showing a significant variation $248(\mathrm{P}<0.05)$ both within and between species and across GIs, and increases at the OG site followed 249 by the MG and the NG site respectively.

\section{The interaction effects of grazing and season on forage nutritive value}

251 The nutritional composition of the forage grasses is significantly different $(\mathrm{p}<0.05)$ among and 252 within species due to the interactive effects of season and GI rate (Table 3). Therefore, the grazing 
253 season affects not only the biomass production of rangelands but also the nutritive value of existing 254 forage grass species in the grazing site. The result indicates that the concentrations of $\mathrm{CP}$, ash, 255 DMD, and DMI content increase during the rainy season compared with those in the dry season. 256 Across all grass species, the highest values of CP, ash, DMD, and DMI content are recorded at the

257 OG site during the rainy season, whereas the lowest values are recorded at the NG site during the 258 dry season.

259 The CP content varies from 1.3\% (A. kenyensis) to $11.4 \%$ (C. ciliari) during the dry season and 260 from $6.9 \%$ (A. kenyensis) to $18.9 \%$ (C. ciliari) during the rainy season. The ash content varies from $2618.1 \%$ (C. roxburghiana) to $14.8 \%$ (C. ciliari) during the dry season and from 13.5\% (C. aucheri) 262 to $21.9 \%$ (D. milanjiana) during the rainy season, indicating that the concentrations of CP and ash 263 are higher during the rainy season than in the dry season. The fiber constituents (i.e., ADF, NDF, 264 and ADL) of the forage grass species increase during the dry season compared with the values in 265 the rainy season. The highest values of ADF, NDF, and ADL are recorded at the NG site during 266 the dry season, whereas the lowest values are recorded at the OG site during the rainy season 267 (Table 3). ADF, NDF and ADL vary from 29.5\% (C. roxburghiana) to 47.1\% (D. milanjiana), 268 from $37.1 \%$ (A. kenyensis) to $60 \%$ (D. milanjiana), and from 13.1\% (A. kenyensis) to $33.7 \%(D$. milanjiana) during the rainy season respectively, and increase in the dry season: from $38.7 \%$ ( $C$. 270 roxburghiana) to $59.9 \%$ (D. milanjiana), from $59.3 \%$ (C. roxburghiana) to $88.5 \%$ (C. ciliary), and 271 from $26.6 \%$ (A. kenyensis) to $53.1 \%$ (C. ciliary) respectively. The interaction effect also impacts 272 the RFV of forage and increases during the rainy season compared with that in the dry season. The 273 maximum RFV is observed during the rainy season across all GIs, highest in the OG site while 274 followed by the MG and NG sites, and lowest during the dry season in the NG site, followed by 275 the MG and OG sites. A. kenyensis, $C$. aucheri and C. roxburghiana show the best, the second best 276 and the third best forage qualities respectively based on our research results.

277 Based on the RFV data, the highest ranking grass species has high CP and ash contents and low 278 fiber components, indicating that high forage quality is generally related to high CP and low fiber 279 contents. Based on this, RFV is assumed to have a direct relationship with CP and ash contents 280 and an inverse relationship with fiber components in forages. All grass species show significantly 281 ( $\mathrm{P}<0.05)$ higher CP, DMD, DMI, and RFV contents and lower ADF, NDF, and ADL contents in 282 the rainy season than in the dry season. The seasonal variation is caused by maturity and age 
283 difference of forage grass species and results in variation in nutritional compositions of forage 284 grass species within the same grazing site.

285

286

287

288

289

290

291

292

293

294

295

296

297

298

299

300

301

302

303

304

305

306

307

308

309

310

311

312

313

\section{Evaluating the proportions of nutritional contents in grass using forage quality index}

Using Principal Component Analysis (PCA), the relationships between nutritional contents and various affecting factors are evaluated. The correlation matrixes of forage nutritional contents related to the impact of the seasonal variation in combination with GI and GI independently are analyzed and illustrated (Table 4 and 5) respectively. The plotted eigenvalues are obtained from the correlation matrixes and variation also calculated and explained by the components (Fig. 5). In Table 4 and 5, there is a strong negative correlation between $\mathrm{CP}$ and ash contents, and fibers (ADF, NDF, and ADL) are observed in all grass species given different grazing season, GI rate, and their interaction effect. RFV shows a strong negative correlation with ADF during the dry season and at the NG site. Component loadings with varimax rotation, as well as the eigenvalues show that there are only two components with eigenvalues higher than one (Fig. 5A) and the total variance is $87.067 \%$ (Table 6). Component 1 contains $60.564 \%$ of the total variance of forage nutrient contents (CP, ash, DMD, DMI, and RFV) and Component 2 contains $25.503 \%$ of the total variance of forage nutrient contents (ADL, NDF, and ADL) (Fig. 5B). On the one hand, a positive correlation exists between CP, DMD, DMI and RFV, as well as between ADF, ADF and ADL of the forage nutrient contents. On the other hand, a negative correlation between fiber contents (ADF, NDF, and ADL) and CP, ash, DMD, DMI, and RFV is observed (Fig. 5B).

\section{DISCUSSION}

In general, our results indicate that the forage nutritive value of all those dominant grass species increases when GI rate increases, corresponding to the findings of previous studies conducted in other arid and semi-arid rangelands across the globe (Fanselow et al., 2011; Haiyan et al., 2016; Schiborra et al., 2009). Rapid increase in GI causes grazing livestock to eat young, regrown protein-rich grasses (Gete \& Gemedo, 2019; Mysterud et al., 2011). As a result, the maturation period of forage grass species is shortened, and the fiber content (ADF, NDF, and ADL) of forage is reduced, whereas the CP content increases when GI increases (Yuan \& Hou, 2015), in direct agreement with the data recorded in our current study.

Forage maturity is inversely related to $\mathrm{CP}$ content and directly related to fiber content. The amount of $\mathrm{CP}$ content is used as an indicator of forage nutritive value, meaning that high forage quality is associated with high CP and low fiber content (Miao et al., 2015; Zhai et al., 2018). Typically, 
314 high CP content is inversely correlated to fiber content (Zhai et al., 2018). Based on the linear 315 regression analysis results, the highest CP content value across all grass species appears in the OG, 316 and the lowest in the NG. The highest fiber content across all grass species is found in the NG and 317 the lowest in the OG. Similar results are reported by Wang et al., (2011) in a study conducted in 318 Inner Mongolia, and also by Miao et al., (2015) in a study conducted on the north-east edge of 319 Qinghai-Tibetan Plateau.

320 Furthermore, our conclusions are consistent with several studies conducted both at the national 321 and international levels in arid and semi-arid rangelands. For example, it was reported that forages 322 with high nutritive value were observed in areas with high GI (Gemedo, 2020; Habtamu et al., 323 2013; Zhang et al., 2015), and the forage nutritive value was enhanced by GI. In the Teltele 324 rangeland, forage nutrient contents show a significant difference $(\mathrm{p}<0.05)$ across all grass species 325 when GI varies. The grass species show a higher amount of DMD, DMI, and FRV when GI 326 increases, and DMI is considered as a positive indicator of forage quality (Arzani et al., 2006).

327 Compared with the nutritive value of species, a higher nutritive response to GI was observed for 328 C. roxburghiana and A. kenyensis, probably because that grazing animals found the species more 329 acceptable at any point of time, resulting in less maturity and faster regrowth rate (Selemani et al., 330 2013; Wan et al., 2011). From this result, we can understand that rangeland management intensity 331 highly affects the forage nutritive value, and grass species in the grazing site have different coping 332 mechanisms to grazing including grazing tolerance (Gamoun, 2014; Ren et al., 2016).

333 When collecting our sample data, the weather condition of the study site is in a normal situation 334 (with no special climate change like drought or flooding). The results show that the forage nutritive 335 value is higher during rainy season than in dry season, which is highly consistent with previous 336 studies conducted by Haiyan et al., (2016) and Müller et al., (2014). In arid and semi-arid 337 rangeland areas of Ethiopia, it was reported that seasonal variation has a significant influence on 338 the nutritional quality of key forage species (Hussain \& Mufakhirah, 2009; Teka et al., 2012). Our 339 results are highly in line with the findings reported by the above authors.

340 In the Teltele rangeland, water scarcity is the major limiting factor for grass species growth. Higher 341 precipitation in the rainy season increases soil water availability and improves species 342 composition. The CP concentration is high during the rainy season because the mineralization rate 343 and nitrogen assimilation of grass species becomes higher (Fig. 6). During the dry season, there is 344 a scarcity of precipitation and consequently a slow regrowth rate, and the forages are highly 
345 mature, resulting in high fiber and low CP concentration (Adogla et al., 2014; Gete \& Gemedo, 346 2019). Compared to the interactive effect of season and GI, the highest forage nutritive value is 347 recorded at rainy season $\times$ OG (overgrazing site during the rainy season), whereas the lowest value 348 is recorded at dry season $\times \mathrm{NG}$ (non-grazing site during the dry season) across all grass species. 349 And C. roxburghiana and A. kenyensis are grass species with higher forage nutritive value in both 350 rainy and dry seasons in all GI treatments.

351 In our study site, grazing reduces the abundance of mature forages and accelerates the regrowth of 352 new grass, leading to less resistance to drought and sensitivity to water loss and causing a 353 significant variation in nutritive value. But still, there is a limitation of data on forage quality during 354 the early growth period since the major impact on CP occurs during the early grazing period 355 (Rawnsley et al., 2002; Sollenberger, 2007). Therefore, rangeland management practices and 356 pastoralists should consider different grazing seasons to obtain the required amount and quality of 357 forage for their livestock.

358 In general, our data indicates that rangeland grass species differ greatly in nutritive value, 359 especially with different GI and seasonal factors. Our data is highly supported by previous studies 360 conducted in arid and semi-arid rangelands around the globe, which revealed the complex impact of both GI and seasonal variation on the forage nutritive value. Such studies included the research

362 conducted by Schönbach, Wan \& Gierus (2012) in Inner Mongolia, by Zhang et al, (2015) in 363 Qilian Mountains, Islam, by Razzaq \& Shamim (2018) in Pakistan, and by Mountousis, 364 Papanikolaou \& Stanogias (2008) in South Europe.

365 Our research results indicate that the forage quality of the dominant grass species in this study 366 shows a significant $(\mathrm{P}<0.05)$ difference. From the recorded data of dominant grass species, $C$. 367 roxburghiana and $D$. milanjiana show the highest and lowest forage quality respectively across all 368 GIs. A negative correlation is found between forage CP and RFV with fiber (ADF, NDF, and 369 ADL) content, and a positive correlation is found between CP, DMD, DMI, and RFV for all species 370 across all GIs and seasons. Our findings are in line with the conclusions reported by Lin et al. 371 (2011), and are in agreement with the data reporting that high Nitrogen (N) forage content has a 372 direct linkage with good nutritional quality (Cao et al., 2011). The negative relationship between $373 \mathrm{~N}(\mathrm{CP})$ and the fiber content of forage is a major indicator of rangeland forage grass species 374 regrowth rate and maturity (Haiyan et al., 2016). Furthermore, the linkage between forage nutritive 375 value indexes is highly affected by both GI and seasonal variation. 
376 Our research results have great implications and can be used as a reference for sustainable 377 management of arid and semi-arid rangelands in Teltele and other areas in Ethiopia, as well as 378 other parts of the world with similar conditions. Since the forage nutritive value fluctuates due to 379 GI and seasonal impact, pastoralists shall make appropriate preparation for the dry season and 380 when over-degradation happens through collecting and providing different supplementary feeds 381 for better livestock management and productivity.

382 The current ongoing grazing intensity and irregular seasonal change may cause rapid rangeland 383 degradation and result in a shortage of forage for livestock grazing, which may lead to social, 384 economic, and political instabilities in the study site and the country in general. The research 385 finding thus plays a critical role in providing information, minimizing the risk of rangeland 386 degradation and cutting the costs of living for both human and livestock. Contrary to our second 387 hypothesis, GI and seasonal variation show a significant impact on the forage nutritive value of 388 the dominant grass species in the study site. The nutritive value of the grass species in Teltele 389 rangeland is more responsive to grazing disturbance, indicating that GI assessment in terms of 390 forage nutritive value is highly important and scientifically recommended for sustainable 391 rangeland management. Our first hypothesis is approved.

\section{CONCLUSIONS}

393 The OG site maintains relatively higher CP and less fiber content in all grass species compared with other GI sites. Seasonal variation is also one of the major determinant factors for forage nutritive value. Higher $\mathrm{CP}$ and less fiber are recorded during the rainy season than in the dry season. Besides the forage nutritive value, both GI and season significantly influence the availability and amount of forage species for grazing. And the shortage of forage under high grazing intensities reduces the livestock carrying capacity of rangeland. Moreover, the exclusion of rangeland from livestock grazing does not necessarily improve forage quality, since high $\mathrm{CP}$ and low fiber concentrations are linked with the GI rate. In the Teltele rangeland, desirable grass species are far from abundant, even in areas where grazing is restricted. This indicates that the most urgent action is to restore these rangelands to a state where dominant species are more 403 prevalent. Therefore, to balance forage availability and quality based on the demand for livestock 404 grazing, adopting sustainable rangeland management strategies like rotational grazing and maintaining grazing intensity at a moderate level are important and recommended for forage producers and pastoralists. 
408

409

410

411

412

413

414

415

416

417

418

419

420

421

422

423

424

425

426

427

428

429

430

431

432

433

434

435

\section{ACKNOWLEDGEMENTS}

The authors wish to thank the University of Chinese Academy of Science and CAS-TWAS fellowship program that provide funding and the PhD Scholarship for the first author. They also acknowledge the African Great Green Wall Adaptation Technical Cooperation Research and Demonstration, Science and Technology Partnership Program, Ministry of Science and Technology of China, and International cooperation and Exchanges NSFC and the CAS Key Technology Talent Program for their financial support to do this paper, also our great thanks go to the local community and stakeholder of the Teltele district for giving us the basic information that are still the challenge for them for our next research step.

\section{O RCI D Id}

Yeneayehu Fenetahun; https://orcid.org/0000-0003-1127-5504

\section{REFERENCE}

Adesogan AT, Sollenberger LE, Newman YC, Vendramini JMB. 2011. Factors affecting forage quality. University of Florida IF AS Extension. Forage Handbook SS-AGR-93.

Adnew W, Tsegay BA, Tassew A, Asmare B. 2018. Assessments of farmers' perception and utilization status of Brachiaria grass in selected areas of Ethiopia. Biodiversitas. 19(3):95162. https ://doi.org/10.13057/biodi v/d1903 26.

Adogla BT, Amaning KK, Ahunu BK. 2014. Effect of season on the quality of forages selected by sheep in citrus plantations in Ghana. Tropical Grasslands - Forrajes Tropicales. 2:271277. DOI: 10.17138/TGFT (2)271-277.

Amiri F, Mohamed AR. 2012. Comparison of nutritive values of grasses and legume species using forage quality index. Songklanakarin Journal of Science and Technology. 34(5): 577586.

Angassa A. 2014. The ecological impact of bush encroachment on the yield of grasses in the Borana rangeland ecosystem. Afr. J. Ecol. 43, 14-20. doi: 10.1111/j.1365-2028.2005.00429. $\mathrm{X}$.

Arzani H, Basiri M, Khatibi F, Ghorbani G. 2006. Nutritive value of some Zagros Mountain rangeland species. Small Ruminant Research. 65(1): 128-135. 
436

437

438

439

440

441

442

443

444

445

446

447

448

449

450

451

452

453

454

455

456

457

458

459

460

461

462

463

464

Asmare B, Solomon D, Taye T, Firew T, Aynalem H, Jane W. 2017. Effects of altitude and harvesting dates on morphological characteristics, yield and nutritive value of desho grass (Pennisetum pedicellatum Trin.) in Ethiopia. Agric Nat Resour. 51:148-53.

Billi P, Alemu YT, Ciampalini R. 2015. Increased frequency of flash floods in the semi-arid Borana lowlands, southern Oromia, Ethiopia: Change in rainfall intensity or human impact? Natural Hazards. 76(2): 1373-1394.

Brisibe EA, Umoren UE, Brisibe F, Magalhäes PM, Ferreira JF, Luthria D, Prior RL. 2009. Nutritional characterisation and antioxidant capacity of different tissues of Artemisia annua L. Food chemistry. 115(4): 1240-1246.

Cao AJ, Holden NM, Luu XT, Du G. 2011. The effect of grazing management on plant species richness on the Qinghai-Tibetan Plateau. Grass \& Forage Science. 66: 333-336.

Cline HJ, Neville BW, Lardy GP, Caton JS. 2009. Influence of advancing season on dietary composition, intake, site of digestion, and microbial efficiency in beef steers grazing a native range in western North Dakota. J. Anim. Sci. 87:375-383.

Coppock DL. 1994. The Borana plateau of southern Ethiopia: Synthesis of pastoral research, development and change. Livestock Center for Africa, Addis Ababa, Ethiopia. 5:1980-91.

Dalle G, Maass BL, Isselstein J. (2015). Rangeland condition and trend in the semi-arid Borana lowlands, southern Oromia, Ethiopia. African Journal of Range \& Forage Science. 23(1): 49-58.

Derner JD. 2009. Livestock and vegetation response to stocking rate and grazing system. Proc. Range Beef Cow Symp. XXI. Pp. 1-8.

Estell RE, Havstad KM, Cibils AF, Anderson DM, Schrader TS. 2014. The changing role of shrubs in rangeland-based livestock production systems: Can shrubs increase our forage supply? Rangelands. 36(2) :25-31.

EMA. 2019. Recorded Rainfall and Temperature Data of Teltele Districts in Borana Rangeland; Ethiopian Meteorological Agency: Addis Ababa, Ethiopia. Unpublished data.

Evitayani L, Warly A, Fariani T, Ichinohe T, Fujihara B. 2004. Seasonal Changes in Nutritive Value of Some Grass Species in West Sumatra, Indonesia. Asian-Aust. J. Anim. Sci. 17(12): 1663-1668. 
465

466

467

468

469

470

471

472

473

474

475

476

477

478

479

480

481

482

483

484

485

486

487

488

489

490

491

492

493

494

495

Fanselow N, Schönbach P, Gong XY. 2011. Short-term regrowth responses of four steppe grassland species to grazing intensity, water and nitrogen in Inner Mongolia. Plant Soil. 340:279-89.

FAO.1988. Guidelines: Land evaluation for extensive grazing. FAO Soil Bulletin No 58. Rome, Italy.

Fazel A, Abdul RB, Mohamed S. 2012. Comparison of nutritive values of grasses and legume species using forage quality index. Songklanakarin J. Sci. Technol. 34 (5): 577-586.

Fenetahun Y, Yuan Y, Xinwen X, Yongdong W, 2021. Effects of Grazing Enclosures on Species Diversity, Phenology, Biomass, and Carrying Capacity in Borana Rangeland, Southern Ethiopia. Front. Ecol. Evol. 8:623627. doi: 10.3389/fevo.2020.623627

Fenetahun Y, Wang YD, You Y, Xu X, 2020. Dynamics of forage and land cover changes in Teltele district of Borana rangelands, southern Ethiopia: using geospatial and field survey data. BMC Ecol. 20:55 https://doi.org/10.1186/s12898-020-00320-8

Gamoun M. 2014. Grazing intensity effects on the vegetation in desert rangelands of Southern Tunisia. Journal of Arid Land. 6: 324-333. doi.org/10.1007/s40333-013-0202-y.

Gelayenew B, Nurfeta A, Assefa G, Asebe G. 2016. Assessment of livestock feed resources in the farming systems of mixed and shifting cultivation, Gambella Regional State, Southwestern Ethiopia. Glob J Sci Front Res. XVI(V):1.

Gemedo D. 2020. Evaluation of forage quantity and quality in the semi-arid Borana Lowlands, Southern Oromia, Ethiopia. Tropical Grasslands-Forrajes Tropicales. 8(2):72-85. doi:10.17138/TGFT (8)72-85.

Gemedo D, Maass BL, Isselstein J. 2005. Plant communities and their species diversity in the semi-arid rangelands of Borana lowlands, southern Oromia, Ethiopia. Community Ecology. 6(2):167-176.

Gete Z, Gemedo D. 2019. Evaluation of nutritive value of some native forage species in Tikur Incinni District, Oromia, Ethiopia. Forage Research. 45:103-110. bit.ly/ 34D5MP3.

Godari A, Ghiyasi S, Poor RA. 2013. Studying Some Chemical Compositions of Sphaerocoma aucheri in Sandy Ranges of Persian Gulf. Journal of applied environmental and biological sciences. 3(5): 36-41.

Habtamu T, Madakadze IC, Angassa A, Hassen A. 2013. Nutritive Value of Grasses in Semiarid Rangelands of Ethiopia: Local Experience Based Herbage Preference Evaluation versus 
496

497

498

499

500

501

502

503

504

505

506

507

508

509

510

511

512

513

514

515

516

517

518

519

520

521

522

523

524

525

526

Laboratory Analysis. Asian-Aust. J. Anim. Sci. $26 \quad$ (3): 366-377. http://dx.doi.org/10.5713/ajas.2012.12551.

Haiyan R, Guodong H, Zhichun L, Hongwei W, Philipp S, Martin G, Friedhelm T. 2016. Grazing effects on herbage nutritive values depend on precipitation and growing season in Inner Mongolian grassland. Journal of Plant Ecology. 9(6):712-723. doi:10.1093/jpe/rtw011.

Henkin N, Ungar ED, Dvash L, Perevolotsky A, Yehuda Y, Sternbergs M, Landau SY. 2011. Effects of cattle grazing on herbage quality in an herbaceous Mediterranean rangeland. Grass Forage Sci. 66:516-525.

Hussain F, Mufakhirah JD. 2009. Nutritional evaluation of some forage plants from Harboi rangeland, Kalat, pakstan. Pak. J. Bot. 41:1137-1154.

Islam M, Razzaq A, Shamim G. 2018. Impact of grazing on soil, vegetation and ewe production performances in a semi-arid rangeland. Journal of Mountain Science. 15(4): 685- 694. https://doi.org/10.1007/s11629-017-4702-7.

Ismail ABO, Fatur M, Ahmed FA, Ahmed EHO, Ahmed MEE. 2014. Nutritive value and palatability of some range grasses in low rainfall woodland savanna of South Darfur in Sudan. Range Management and Agroforestry. 35(2): 193-197.

Jank L, Barrios SC, DoValle CB, Simeao RM, Alves GF. 2014. The value of improved pastures to Brazilian beef production. Crop Pasture Sci. 65:1132. https ://doi.org/10.1071/cp133 19.

Juárez AS, Cerrillo MA, La OO, Herrera RS, Scull I, Guerero M, Bernal H. 2013. Nutritional value and kinetics of the ruminal fermentation of flowers, tree fruits and shrubs in the Cauto Valley, Cuba. Cuban Journal of Agricultural Science, 47(1).

Kaplan M, Kamalak A, Kasra AA, GÜVEN İ. 2014. Effect of Maturity Stages on Potential Nutritive Value, Methane Production and Condensed Tannin Content of Sanguisorba minor Hay. Kafkas Üniversitesi Veteriner Fakültesi Dergisi. 20(3): 445-449.

Kirch GH, Moser L E, Waller SS, Klopfenstein TJ, Aiken GE, Strickland JR. 2007. Selection and dietary quality of beef cattle grazing smooth bromegrass, switchgrass, and big bluestem. Prof. Anim. Sci. 23:672-680.

Lin LJ, Dickhoefer U, Muller K, Wurin A, Susenbth A. 2011. Grazing behavior of sheep at different stocking rates in the Inner Mongolian steppe, China. Applied Animal Behaviour Science. 129: 36-42. 
527 Massey FP, Ennos AR, Hartley SE. 2007. Herbivore specific induction of silica-based plant 528 defences. Oecologia. 152(4):677-683.

529

530

531

532

533

534

535

536

537

538

539

540

541

542

543

544

545

546

547

548

549

550

551

552

553

554

555

556

557

Miao F, Guo Z, Xue R, Wang X, Shen Y. 2015. Effects of grazing and precipitation on herbage biomass, herbage nutritive value, and yak performance in an alpine meadow on the QinghaiTibetan Plateau. PLoS ONE. https://doi.org/10.1371/journal.pone.0127275.

Mountousis I, Papanikolaou K, Stanogias G. 2008. Seasonal variation of chemical composition and dry matter digestibility of rangelands in NW Greece. Journal of Central European Agriculture. 9(3): 547-556.

Müller K, Dickhoefer U, Lin L. 2014. Impact of grazing intensity on herbage quality, feed intake and live weight gain of sheep grazing on the steppe of Inner Mongolia. J Agric Sci. 152:15365 .

Mysterud A, Hessen DO, Mobaek R. 2011. Plant quality, seasonality and sheep grazing in an alpine ecosystem. Basic Appl Ecol. 12:195-206.

Newman YC, Lambert B, Muir JP. 2009. Defining forage quality. EDIS Publication SS-AGR322. Gainesville, FL: Agronomy Department, UF/IFAS Extension Service.

Njidda AA, Olatunji EA, Raji AY. 2012. Semi-arid browse forages: Their antinutritive substances and in sacco neutral detergent fibre and organic matter degradability.1(6), 21-30.

Rawnsley RP, Donaghy DJ, Fulkerson WJ, Lane PA. 2002. Changes in the physiology and feed quality of cocksfoot (Dactylis glomerata L.) during regrowth. Grass and forage science. 57(3), 203-211.

Ren H, Han G, Schönbach P. 2016. Forage nutritional characteristics and yield dynamics in a grazed semiarid steppe ecosystem of Inner Mongolia, China. Ecological Indicators. 60: 460469. https://doi.org/10.1016/j.ecolind.2015.07.027.

Samuels I, Cupido C, Swarts MB, Palmer AR, Paulse JW. 2015. Feeding ecology of four livestock species under different management in a semi-arid pastoral system in South Africa. African Journal of Range and Forage Science, 1-9.

Schacht WH, Volesky JD, Stephenson MB, Klopfenstein TJ, Adams DC. 2010. Plant and animal responses to grazing systems in the Nebraska Sandhills.NE Beef Rep. p. 36-37.

Schiborra A, Gierus M, Wan H. 2009. Short-term responses of a Stipa grandis/Leymus chinensis community to frequent defoliation in the semi-arid grasslands of Inner Mongolia, China. Agric Ecosyst Environ. 132:82-90.

Peer) reviewing PDF | (2020:10:53562:4:0:NEW 25 Aug 2021) 
558 Schönbach P, Wan H, Gierus M. 2012. Effects of grazing and precipitation on herbage

559

560

561

562

563

564

565

566

567

568

569

570

571

572

573

574

575

576

577

578

579

580

581

582

583

584

585

586

587 production, herbage nutritive value and performance of sheep in continental steppe. Grass and Forage Science. 67: 535-545. https://doi.org/10.1111/j.1365-2494.2012.00874.x.

Schut AGT, Gherardi SG, Wood DA. 2010. Empirical models to quantify the nutritive characteristics of annual pastures in south-west Western Australia. Crop and Pasture Science. 61(1), 32-43.

Selemani IS, Eik LO, Holand Ø, Adnoy T, Mtengeti E, Mushi D. 2013. Variation in quantity and quality of native forages and grazing behavior of cattle and goats in Tanzania. Livest Sci. 157(1):173-83.

Shah NH, Paulsen GM. 2003. Interaction of drought and high temperature on photosynthesis and grain-filling of wheat. Plat and Soil. 257:219-226.

Smart AJ, Derner JD, Hendrickson JR, Gillen RL, Dunn BH, Mousel EM, Olson KC. 2010. Grazing pressure efficiency of grazing on North American Great Plains Rangelands. Rangeland Ecol. Manage. 63:397-406.

Sollenberger LE. 2007. Grazing Management. In: R.F. Barnes, editor, Forages volume II: The science of grassland agriculture. Blackwell publishing, Ames, IA. p. 651-659.

Teka H, Madakadze I C, Angassa A, Hassen A. 2012. Effect of seasonal variation on the nutritional quality of key herbaceous species in semi-arid areas of Borana, Ethiopia. Indian Journal of Animal Nutrition. 4, 324-332.

Undersander D, Mertens D, Thiex N. 1993. Forage analyses. National Forage Testing Association. USA.

VanSoest PJ, Robertson JB, Lewis BA. 2015. Methods for dietary fiber, neutral detergent fiber, and non-starch polysaccharides in relation to animal nutrition. J Dairy Sci. 74(10):3583-97.

Vendramini V. 2010. Forage Evaluation and Quality in Florida. In Proceedings. The $21^{\text {st }}$ Annual Florida Ruminat Nutrition Symposium. Best Western Gateway Grand Hotel Gainesville, Florida, Department of Animal Sciences University of Florida. Institute of Food and Agricultural Sciences Gainesville, Florida (2-3).

Wan H, Bai Y, Schönbach, P. 2011. Effects of grazing management system on plant community structure and functioning in a semiarid steppe: scaling from species to community. Plant Soil. 340:215-26. 
588 Wang C, Wang S, Zhou H. 2011. Influence of grassland degradation on forage availability by 589 sheep in the Inner Mongolian steppes of China. Animal Science Journal. 82(4): 537-542. $590 \quad$ https://doi.org/10.1111/j.1740-0929.2011.00878.x.

591 Wubetie A, Berhanu A, Asaminew T, Bimrew A. 2018. Evaluation of morphological 592 characteristics, yield and nutritive value of Brachiaria grass ecotypes in northwestern 593 Ethiopia. Agric \& Food Secur. 7:89. https://doi.org/10.1186/s40066-018-0239-4.

594 Xiajie Z, Yingjun Z, Kun W, Qian C, Shuiyan L, Ding H. 2018. Grazing effects on the nutritive 595 596 597 598 value of dominant species in steppe grasslands of northern China. BMC Ecol. 18:30. http://doi.org/10.1186/s12898-018-0186-8.

Yeneayehu F, Xu X.W, Wang Y. D. 2020. Forage composition, biomass and carrying capacity dynamics in Yabello rangeland, southern Ethiopia. Using different grazing sites. Appl. Ecol. Environ. Res. 18, 7233-7253. doi: 10.15666/ aeer/1805_72337253.

Yuan H, Hou F. 2015. Grazing intensity and soil depth effects on soil properties in alpine meadow pastures of Qilian Mountain in northwest China. Acta Agriculture Scandinavica, Section BSoil\& Plant Science 65: 222-232. doi.org/10.1080/09064710.2014.992940.

604

605

Zhang Y, Chen X, Cheng Y. 2015. Effects of stocking rates on functional group diversity and forage quality in rangeland of Qilian Mountain, China. Journal of Environmental Biology.

606 
Figure 1

Location map of the study area and sampling plot layout. 


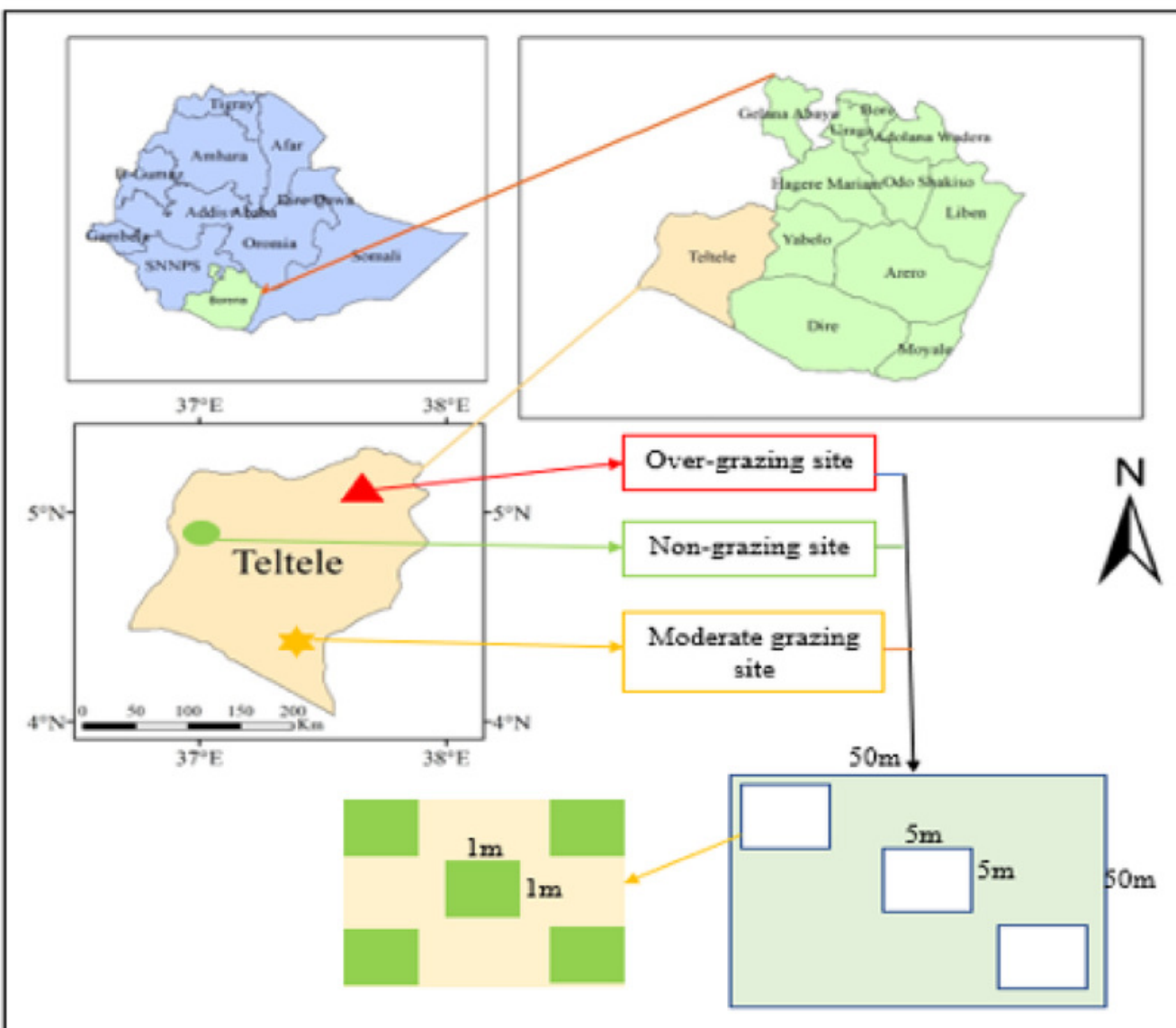

Total = 5 plots $X 3$ sub-plots $X 5$ quadrats $X 2$ seasons $X 3$ replications for each grazing aite 
Figure 2

Mean annual rainfall (RF) and temperature (Temp) from 2008- 2019 in the Teltele rangeland site.

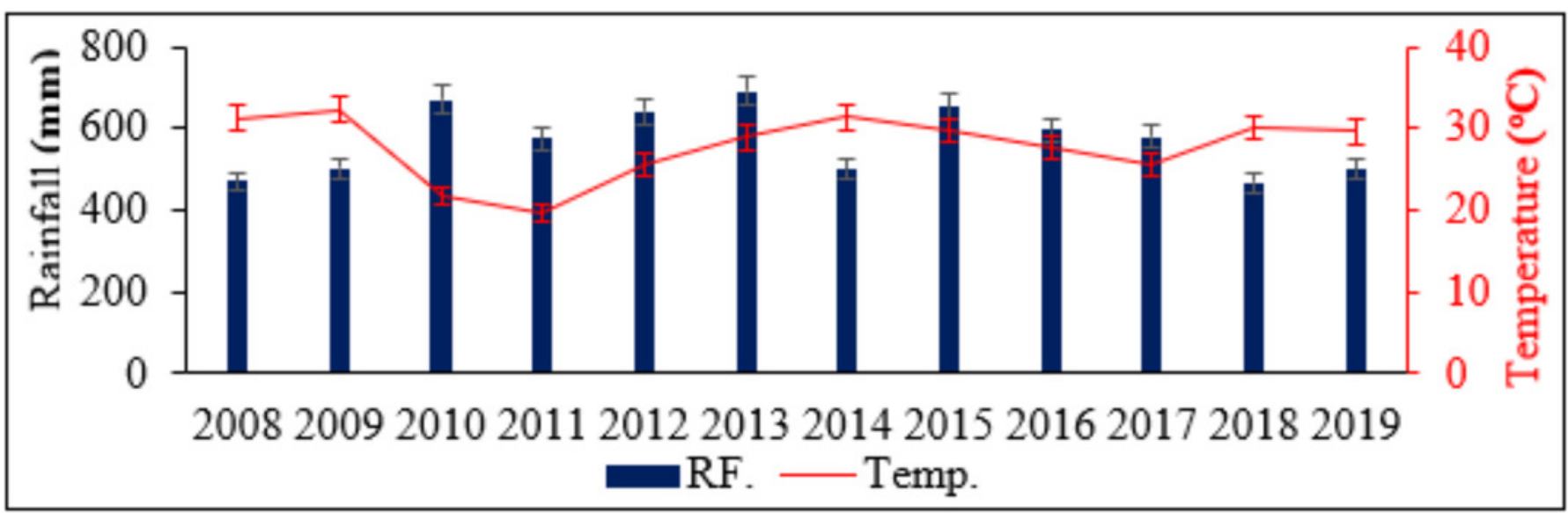


Figure 3

Relative abundance of dominant grass species in the Teltele rangeland.

$\mathbf{R s}=$ rainy season, $\mathbf{D s}=$ dry season.

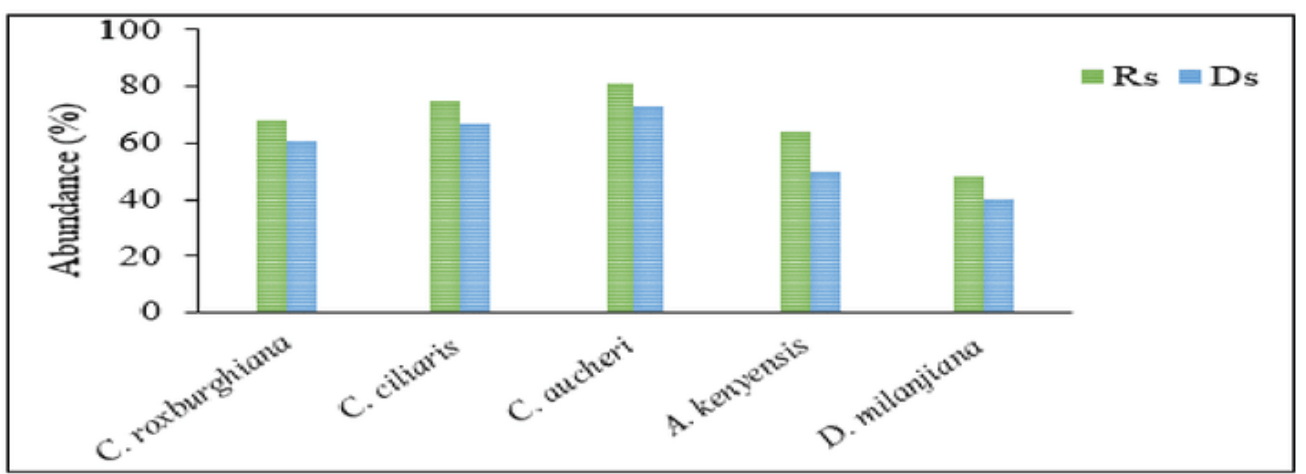


Figure 4

Relationship between stocking rate (SR) and forage nutritive values of each grass species.

$\mathbf{A}=C$. roxburghiana, $\mathbf{B}=C$. ciliary, $\mathbf{C}=C$. aucheri, $\mathbf{D}=A$. kenyensis and $\mathbf{E}=D$. milanjiana.

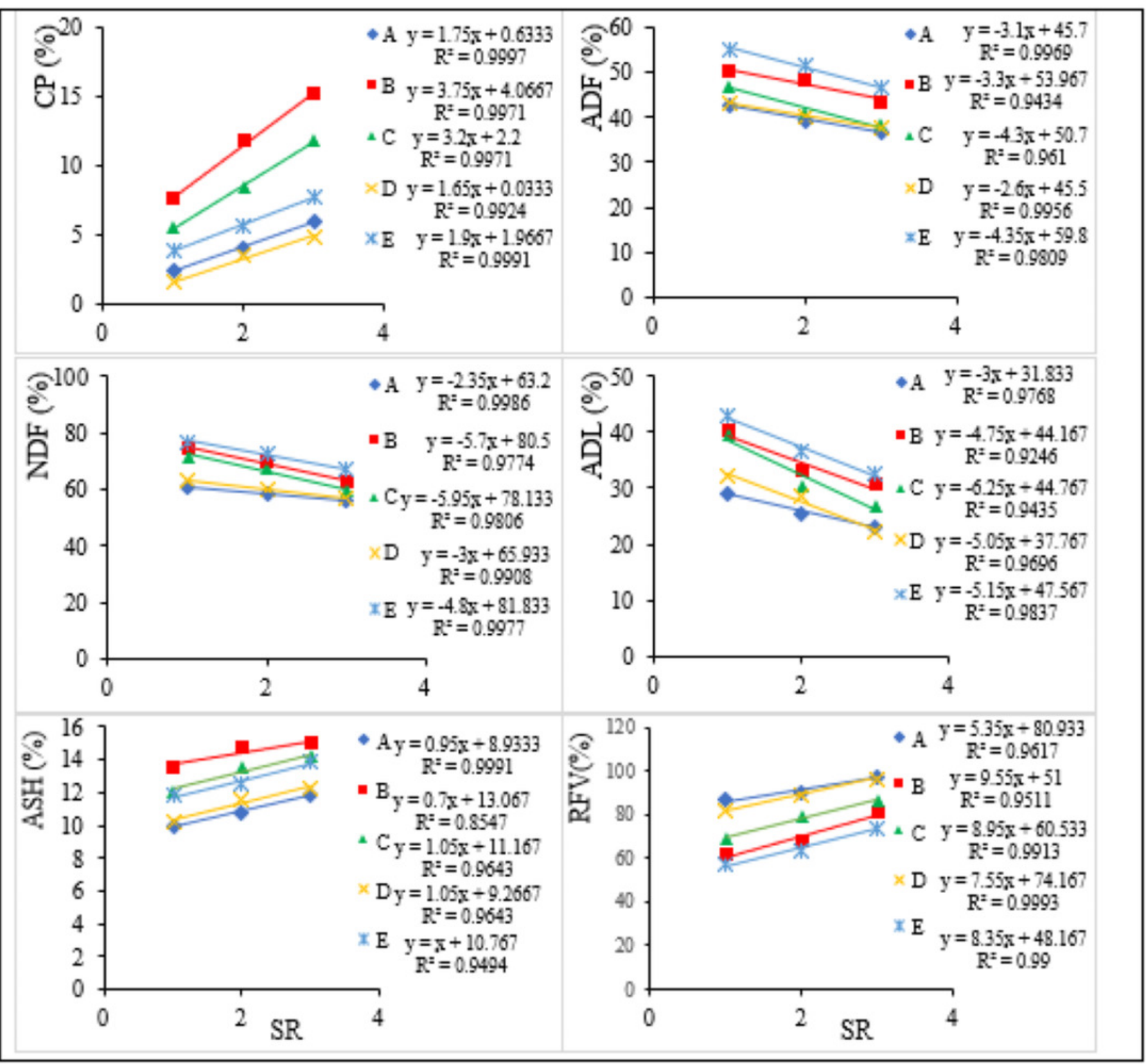


Figure 5

Scree plot: Eigenvalues plotted in descending order (A) and Principal Components in a two-dimensiotal space (B).
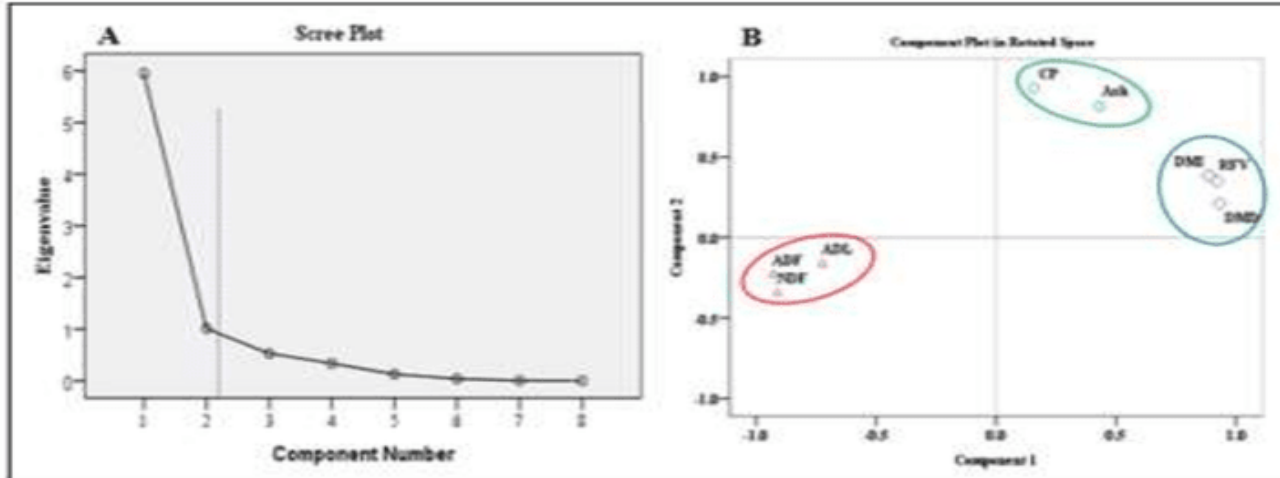
Figure 6

The mean forage nutrient concentration (\%) at rainy season and dry season under different grazing intensity. Error bars indicate standard error.

$\mathbf{D s}=$ dry season, $\mathbf{R s}=$ rainy season, $\mathbf{C P}=$ crude protein, $\mathbf{A D F}=$ acid detergent fiber, $\mathbf{N D F}=$ neutral detergent fiber, $\mathbf{A D L}=$ acid detergent lignin, $\mathbf{D M D}=$ dry matter digestibility, $\mathbf{D M I}=$ dry matter intake $\mathbf{R F V}=$ relative feed/forage value 


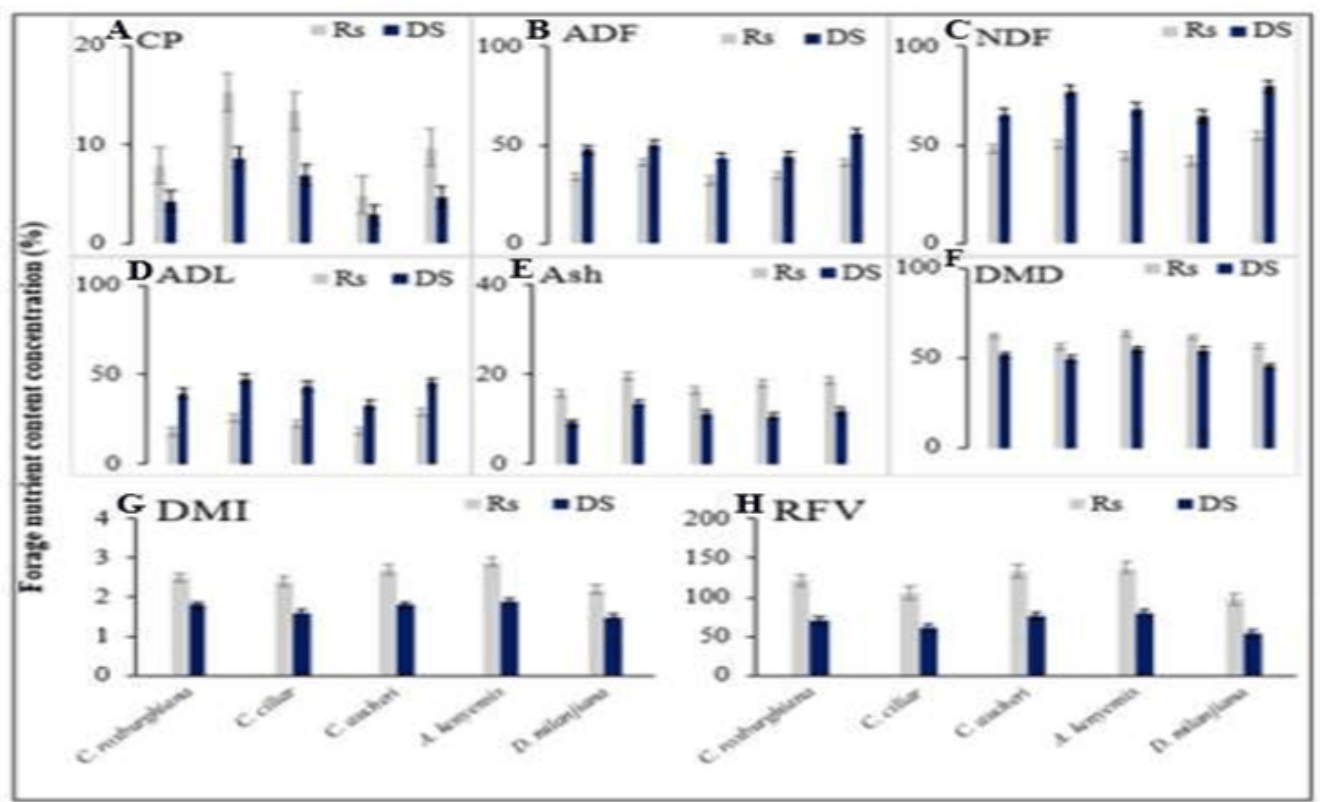




\section{Table $\mathbf{1}$ (on next page)}

Standard procedures and methods used to analyses forage nutritive value

$\mathrm{DMD}=$ dry matter digestibility, $\mathrm{DMI}=$ dry matter intake. 
1 TABLE 1 Standard procedures and methods used to analyses forage nutritive value

\begin{tabular}{|c|c|c|}
\hline $\begin{array}{l}\text { Major forage nutrition } \\
\text { compositions }\end{array}$ & $\begin{array}{l}\text { Analyses procedures and } \\
\text { methods used }\end{array}$ & Reference \\
\hline Crude protein $(\mathrm{CP})$ & AOAC (1995) & Zhai et al., (2018) \\
\hline Acid detergent fiber (ADF) & Acid detergent solution & $\begin{array}{l}\text { Van Soest, Robertson \& } \\
\text { Lewis, (2015) }\end{array}$ \\
\hline Neutral detergent fiber (NDF) & Neutral washing liquid & Van Soest et al., (2015) \\
\hline Acid detergent lignin (ADL) & ANKOM 200 Fiber Analyzed & Van Soest et al., (2015) \\
\hline Ash contents & AOAC (1990) & Zhai et al., (2018) \\
\hline $\begin{array}{l}\text { Relative feed/forage value } \\
\text { (RFV) }\end{array}$ & $\begin{array}{l}\mathrm{RFV}=(\% \mathrm{DMD} \times \% \mathrm{DMI}) \div 1.29 \\
\text { Where } 1.29=\text { the expected } \\
\text { digestible dry matter intake as } \% \text { of } \\
\text { body weight; DMD }=88.9- \\
(\mathrm{ADF} \% \times 0.779), \mathrm{DMI}=120 / \% \\
\text { NDF. }\end{array}$ & $\begin{array}{l}\text { Newman et al., (2009); } \\
\text { Schacht, Volesky, } \\
\text { Stephenson, Klopfenstein \& } \\
\text { Adams (2010) }\end{array}$ \\
\hline
\end{tabular}

2

$3 \mathrm{DMD}=$ dry matter digestibility, $\mathrm{DMI}=$ dry matter intake. 


\section{Table 2 (on next page)}

Effects of grazing intensity on forage nutritive value of each grass species

Values in columns with different lower-case letters (a, b--etc) are significantly different $(p<0.05)$ and values with the same second double lower-case letters under some treatment ( $a a, b a, c c, b c-e t c$ ) and values with both lower case and upper-case letters across the treatment $(a B,--$ etc) are indicated not significant difference $(p>0.05) . \mathrm{Gl}=$ grazing intensity, $\mathrm{NG}=$ non- grazing, $\mathrm{MG}=$ moderate grazing, $\mathrm{OG}=$ over grazing, $\mathrm{CP}=$ crude protein, $\mathrm{ADF}=$ acid detergent fiber, $\mathrm{NDF}=$ neutral detergent fiber, $\mathrm{ADL}=$ acid detergent lignin, $\mathrm{DMD}=$ dry matter digestibility, $\mathrm{DMI}=$ dry matter intake $\mathrm{RFV}=$ relative feed/forage value. 
1 TABLE 2 Effects of grazing intensity on forage nutritive value of each grass species

\begin{tabular}{|c|c|c|c|c|c|c|c|c|c|}
\hline \multirow[t]{2}{*}{ GI } & \multirow[t]{2}{*}{ Grass species } & \multicolumn{8}{|c|}{ Forage nutrient compositions (\%) } \\
\hline & & $\mathrm{CP}$ & $\mathrm{ADF}$ & $\mathrm{NDF}$ & $\mathrm{ADL}$ & Ash & DMD & DMI & RFV \\
\hline \multirow[t]{5}{*}{$\mathrm{NG}$} & C. roxburghiana & $2.4^{\mathrm{a}}$ & $42.7^{\mathrm{aB}}$ & $60.8^{\mathrm{aB}}$ & $29.1^{\mathrm{aA}}$ & $9.9^{\mathrm{aaA}}$ & $56.1^{\mathrm{a}}$ & $2.0^{\mathrm{aaA}}$ & $86.9^{\mathrm{aA}}$ \\
\hline & C. ciliar & $7.7^{\mathrm{bE}}$ & $50.2^{\mathrm{b}}$ & $74.3^{\mathrm{b}}$ & $40.2^{\mathrm{b}}$ & $13.6^{\mathrm{bB}}$ & $49.8^{\mathrm{b}}$ & $1.6^{\mathrm{bbB}}$ & $61.8^{\mathrm{b}}$ \\
\hline & C. aucheri & $5.5^{\mathrm{cC}}$ & $46.9^{\mathrm{cA}}$ & $71.7^{\mathrm{c}}$ & $39.4^{\mathrm{b}}$ & $12.1^{\mathrm{cC}}$ & $52.4^{\mathrm{cA}}$ & $1.7^{\mathrm{dbB}}$ & $69.0^{\mathrm{c}}$ \\
\hline & A. kenyensis & $1.6^{\mathrm{d}}$ & $43.0^{\mathrm{d}}$ & $63.1^{\mathrm{dC}}$ & $32.2^{\mathrm{cB}}$ & $10.2^{\mathrm{daA}}$ & $55.4^{\mathrm{aB}}$ & $1.9^{\mathrm{caC}}$ & $81.6^{\mathrm{d}}$ \\
\hline & D. milanjiana & $3.9^{\mathrm{e}}$ & $55.1^{\mathrm{e}}$ & $76.9^{\mathrm{e}}$ & $42.8^{\mathrm{d}}$ & $11.9^{\mathrm{cC}}$ & $46.0^{\mathrm{e}}$ & $1.6^{\mathrm{bbB}}$ & $57.0^{\mathrm{e}}$ \\
\hline \multirow[t]{5}{*}{ MG } & C. roxburghiana & $4.1^{\mathrm{cc}}$ & $39.3^{\mathrm{c}}$ & $58.6^{\mathrm{c}}$ & $25.3^{\mathrm{c}}$ & $10.8^{\mathrm{cA}}$ & $58.3^{\mathrm{cC}}$ & $2.0^{\mathrm{aaA}}$ & $90.4^{\mathrm{c}}$ \\
\hline & C. ciliari & $11.8^{\mathrm{dD}}$ & $48.3^{\mathrm{d}}$ & $70.1^{\mathrm{d}}$ & $33.1^{\mathrm{d}}$ & $14.8^{\mathrm{d}}$ & $51.3^{\mathrm{d}}$ & $1.7^{\mathrm{bbB}}$ & $67.6^{\mathrm{d}}$ \\
\hline & C. aucheri & $8.4^{\mathrm{e}}$ & $41.1^{\mathrm{ee}}$ & $67.2^{\mathrm{eA}}$ & $30.5^{\mathrm{e}}$ & $13.5^{\mathrm{bB}}$ & $56.9^{\mathrm{e}}$ & $1.8^{\mathrm{dC}}$ & $79.4^{\mathrm{e}}$ \\
\hline & A. kenyensis & $3.5^{\mathrm{c}}$ & $40.1^{\mathrm{ee}}$ & $59.6^{\mathrm{c}}$ & $28.7^{\mathrm{bA}}$ & $11.6^{\mathrm{bbC}}$ & $61.6^{\mathrm{b}}$ & $2.0^{\mathrm{caA}}$ & $89.5^{\mathrm{b}}$ \\
\hline & D. milanjiana & $5.7^{\mathrm{bA}}$ & $51.8^{\mathrm{b}}$ & $72.5^{\mathrm{b}}$ & $36.5^{\mathrm{a}}$ & $12.5^{\mathrm{abC}}$ & $48.5^{\mathrm{a}}$ & $1.7^{\mathrm{dbB}}$ & $63.9^{\mathrm{a}}$ \\
\hline \multirow[t]{5}{*}{ OG } & C. roxburghiana & $5.9^{\mathrm{eA}}$ & $36.5^{\mathrm{e}}$ & $56.1^{\mathrm{e}}$ & $23.1^{\mathrm{e}}$ & $11.8^{\mathrm{b}}$ & $60.0^{\mathrm{e}}$ & $2.1^{\text {aa }}$ & $97.6^{\mathrm{eb}}$ \\
\hline & C. ciliari & $15.2^{\mathrm{c}}$ & $43.6^{\mathrm{aB}}$ & $62.9^{\mathrm{cC}}$ & $30.7^{\mathrm{c}}$ & $15.0^{\mathrm{a}}$ & $54.9^{\mathrm{aB}}$ & $1.9^{\mathrm{ebC}}$ & $80.9^{c}$ \\
\hline & C. aucheri & $11.9^{\mathrm{dD}}$ & $38.3^{\mathrm{dd}}$ & $59.8^{\mathrm{bB}}$ & $26.9^{d}$ & $14.2^{\mathrm{d}}$ & $59.0^{\mathrm{ddC}}$ & $1.9^{\mathrm{bbC}}$ & $86.9^{\mathrm{dA}}$ \\
\hline & A. kenyensis & $4.9^{\mathrm{bcC}}$ & $37.8^{\mathrm{cd}}$ & $57.1^{\mathrm{e}}$ & $22.1^{\mathrm{a}}$ & $12.3^{\mathrm{bC}}$ & $59.4^{\mathrm{cdC}}$ & $2.1^{\mathrm{ba}}$ & $96.7^{\mathrm{ab}}$ \\
\hline & D. milanjiana & $7.7^{\mathrm{aE}}$ & $46.4^{\mathrm{aA}}$ & $67.3^{\mathrm{aA}}$ & $32.5^{\mathrm{bB}}$ & $13.9^{\mathrm{eB}}$ & $52.8^{\mathrm{bA}}$ & $1.8^{\mathrm{dbC}}$ & $73.7^{\mathrm{b}}$ \\
\hline
\end{tabular}

2 Note. Values in columns with different lower-case letters (a, b--etc) are significantly different

$3(p<0.05)$ and values with the same second double lower-case letters under some treatment (aa, 4 ba, cc, bc - etc) and values with both lower case and upper-case letters across the treatment (aB, 5 -- etc) are indicated not significant difference $(\mathrm{p}>0.05)$. GI $=$ grazing intensity, $\mathrm{NG}=$ non-

6 grazing, $\mathrm{MG}=$ moderate grazing, $\mathrm{OG}=$ over grazing, $\mathrm{CP}=$ crude protein, $\mathrm{ADF}=$ acid detergent

7 fiber, $\mathrm{NDF}=$ neutral detergent fiber, $\mathrm{ADL}=$ acid detergent lignin, $\mathrm{DMD}=$ dry matter

8 digestibility, $\mathrm{DMI}=$ dry matter intake $\mathrm{RFV}=$ relative feed/forage value. 


\section{Table 3 (on next page)}

Interaction effects of seasonal variation and GI on forage nutritive value of each grass species

Values in columns with different lower-case letters ( $a, b$--etc) are significantly different $(p<0.05)$ and values with the some second double lower case letters under the some treatment (aa, ba, cc, bc-etc) and values with both lower case and upper case letters across the treatment $(a B, a b A, a c B D--~ e t c)$ are indicated not significant difference $(p>0.05) . G I=$ grazing intensity, Ds = dry season, $\mathrm{Rs}=$ rainy season, $\mathrm{NG}=$ non- grazing, $\mathrm{MG}=$ moderate grazing, $\mathrm{OG}=$ over grazing, $\mathrm{CP}=$ crude protein, $\mathrm{ADF}=$ acid detergent fiber, $\mathrm{NDF}=$ neutral detergent fiber, $A D L=$ acid detergent lignin, $D M D=$ dry matter digestibility, $D M I=$ dry matter intake RFV = relative feed/forage value. 
1 TABLE 3 Interaction effects of seasonal variation and GI on forage nutritive value of each grass 2 species

\begin{tabular}{|c|c|c|c|c|c|c|c|c|c|}
\hline \multirow[t]{2}{*}{ Treatment } & \multirow[t]{2}{*}{ Grass species } & \multicolumn{8}{|c|}{ Forage nutrient compositions (\%) } \\
\hline & & $\mathrm{CP}$ & $\mathrm{ADF}$ & NDF & ADL & Ash & DMD & DMI & RFV \\
\hline \multirow[t]{5}{*}{ Rs X NG } & C. roxburghiana & $5.9^{\mathrm{ab}}$ & $38.1^{\mathrm{aaB}}$ & $53.2^{\mathrm{aA}}$ & $21.5^{\mathrm{aA}}$ & $14.1^{\text {aa }}$ & $59.2^{\mathrm{aaA}}$ & $2.3^{\mathrm{aaA}}$ & $106^{\mathrm{a}}$ \\
\hline & C. ciliar & $10.9^{\mathrm{bE}}$ & $44.7^{\mathrm{b}}$ & $56.3^{\mathrm{b}}$ & $30.8^{\mathrm{b}}$ & $17.7^{\mathrm{bA}}$ & $54.1^{\mathrm{b}}$ & $2.1^{\mathrm{bdB}}$ & $88^{\mathrm{b}}$ \\
\hline & C. aucheri & $10.6^{\mathrm{cC}}$ & $34.9^{\mathrm{cA}}$ & $50.4^{\mathrm{cB}}$ & $28.8^{\mathrm{bB}}$ & $13.5^{\mathrm{ca}}$ & $61.7^{\mathrm{cB}}$ & $2.4^{\mathrm{aaA}}$ & $115^{\mathrm{caA}}$ \\
\hline & A. kenyensis & $2.9^{\mathrm{d}}$ & $37.4^{\mathrm{daE}}$ & $47.2^{\mathrm{dC}}$ & $23.2^{\mathrm{c}}$ & $15.7^{\mathrm{dbB}}$ & $59.8^{\mathrm{aaA}}$ & $2.5^{\mathrm{aaC}}$ & $116^{\mathrm{daA}}$ \\
\hline & D. milanjiana & $7.8^{\mathrm{ebC}}$ & $47.1^{\mathrm{e}}$ & $60.0^{\mathrm{e}}$ & $33.7^{\mathrm{d}}$ & $16.4^{\mathrm{cbB}}$ & $52.2^{\mathrm{e}}$ & $2.0^{\mathrm{bdB}}$ & $81^{\mathrm{e}}$ \\
\hline \multirow[t]{5}{*}{ Rs X MG } & C. roxburghiana & $7.8^{\mathrm{cC}}$ & $34.3^{\mathrm{ceA}}$ & $48.1^{\mathrm{cC}}$ & $17.9^{\mathrm{c}}$ & $15.8^{\mathrm{ccB}}$ & $62.2^{\mathrm{cbB}}$ & $2.5^{\mathrm{baC}}$ & $121^{\mathrm{cB}}$ \\
\hline & C. ciliari & $16.1^{\mathrm{dD}}$ & $41.3^{\mathrm{db}}$ & $50.5^{\mathrm{dB}}$ & $25.1^{\mathrm{d}}$ & $19.9^{\mathrm{dC}}$ & $56.7^{\mathrm{dc}}$ & $2.4^{\mathrm{baA}}$ & $105^{\mathrm{d}}$ \\
\hline & C. aucheri & $12.8^{\mathrm{eE}}$ & $31.8^{\mathrm{e}}$ & $45.3^{\mathrm{eA}}$ & $21.2^{\mathrm{eaA}}$ & $16.5^{\mathrm{bcB}}$ & $64.1^{\mathrm{e}}$ & $2.6^{\mathrm{baC}}$ & $129^{\mathrm{e}}$ \\
\hline & A. kenyensis & $4.8^{\mathrm{c}}$ & $35.1^{\mathrm{ee}}$ & $41.9^{c}$ & $19.6^{\mathrm{baA}}$ & $18.0^{\mathrm{bdD}}$ & $61.6^{\mathrm{bbB}}$ & $2.9^{\mathrm{cE}}$ & $138^{\mathrm{bC}}$ \\
\hline & D. milanjiana & $10.2^{\mathrm{bA}}$ & $41.2^{\mathrm{bb}}$ & $54.1^{\mathrm{bA}}$ & $29.1^{\mathrm{aB}}$ & $17.5^{\mathrm{adA}}$ & $56.8^{\mathrm{ac}}$ & $2.2^{\mathrm{eB}}$ & $97^{\mathrm{a}}$ \\
\hline \multirow[t]{5}{*}{ Rs X OG } & C. roxburghiana & $9.9^{\mathrm{eE}}$ & $29.5^{\mathrm{e}}$ & $43.9^{\mathrm{e}}$ & $14.7^{\mathrm{e}}$ & $17.3^{\mathrm{bAD}}$ & $65.9^{\mathrm{ee}}$ & $2.7^{\mathrm{eeE}}$ & $138^{\mathrm{eC}}$ \\
\hline & C. ciliari & $18.9^{\mathrm{c}}$ & $38.2^{\mathrm{aB}}$ & $45.2^{\mathrm{cC}}$ & $21.3^{\mathrm{cA}}$ & $21.2^{\mathrm{afe}}$ & $59.1^{\mathrm{aA}}$ & $2.7^{\mathrm{deE}}$ & $124^{\mathrm{cB}}$ \\
\hline & C. aucheri & $16.7^{\mathrm{dD}}$ & $30.0^{\mathrm{d}}$ & $38.8^{\mathrm{b}}$ & $18.1^{\mathrm{d}}$ & $19.2^{\mathrm{df}}$ & $65.5^{\mathrm{de}}$ & $3.1^{\mathrm{cb}}$ & $157^{\mathrm{db}}$ \\
\hline & A. kenyensis & $6.9^{\mathrm{bcC}}$ & $31.9^{c}$ & $37.1^{\mathrm{e}}$ & $13.1^{\mathrm{a}}$ & $20.3^{\mathrm{beC}}$ & $64.0^{\mathrm{c}}$ & $3.2^{\mathrm{db}}$ & $159^{\mathrm{ab}}$ \\
\hline & D. milanjiana & $11.2^{\mathrm{aE}}$ & $34.6^{\mathrm{aA}}$ & $49.9^{\mathrm{aB}}$ & $24.5^{\mathrm{b}}$ & $21.9^{\text {ee }}$ & $61.9^{\mathrm{bB}}$ & $2.4^{\mathrm{aA}}$ & $115^{\mathrm{bA}}$ \\
\hline \multirow[t]{5}{*}{$\overline{D s} \mathrm{XNG}$} & C. roxburghiana & $2.2^{\mathrm{a}}$ & $55.2^{\text {aa }}$ & $72.8^{\mathrm{aA}}$ & $49.9^{a}$ & $8.1^{\text {aa }}$ & $45.9^{\text {aa }}$ & $1.6^{\mathrm{aaA}}$ & $56.9^{\mathrm{a}}$ \\
\hline & C. ciliari & $6.6^{\mathrm{bB}}$ & $54.4^{\text {ba }}$ & $88.5^{\mathrm{bb}}$ & $53.1^{\mathrm{e}}$ & $12.0^{\mathrm{bA}}$ & $46.5^{\mathrm{ba}}$ & $1.4^{\mathrm{bb}}$ & $50.5^{\mathrm{b}}$ \\
\hline & C. aucheri, & $4.4^{\mathrm{cC}}$ & $49.7^{\mathrm{cA}}$ & $77.0^{\mathrm{cB}}$ & $51.2^{\mathrm{bb}}$ & $9.1^{\mathrm{cB}}$ & $50.2^{\mathrm{cA}}$ & $1.6^{\mathrm{daA}}$ & $62.3^{\mathrm{cA}}$ \\
\hline & A. kenyensis & $1.3^{\mathrm{d}}$ & $48.0^{\mathrm{d}}$ & $69.3^{\mathrm{dC}}$ & $39.4^{\mathrm{cA}}$ & $8.9^{\mathrm{daB}}$ & $51.5^{\mathrm{a}}$ & $1.7^{\mathrm{caA}}$ & $67.9^{\mathrm{d}}$ \\
\hline & D. milanjiana & $3.5^{\mathrm{eDC}}$ & $59.9^{\mathrm{e}}$ & $87.9^{\mathrm{eb}}$ & $51.6 \mathrm{~d}^{\mathrm{b}}$ & $10.4^{\mathrm{c}}$ & $42.2^{\mathrm{e}}$ & $1.4^{\mathrm{bb}}$ & $45.8^{\mathrm{e}}$ \\
\hline \multirow[t]{5}{*}{ Ds X MG } & C. roxburghiana & $3.9^{\mathrm{cC}}$ & $49.3^{\mathrm{ccA}}$ & $64.6^{\mathrm{c}}$ & $38.6^{\mathrm{cA}}$ & $9.3^{\mathrm{cB}}$ & $50.3^{\mathrm{cbA}}$ & $1.9^{\mathrm{acB}}$ & $74.1^{\mathrm{ca}}$ \\
\hline & C. ciliari & $8 . .2^{\mathrm{dD}}$ & $49.9^{\mathrm{dcA}}$ & $77.1^{\mathrm{dB}}$ & $48.0^{\mathrm{d}}$ & $14.8^{\mathrm{d}}$ & $50.0^{\mathrm{dbA}}$ & $1.6^{\mathrm{beA}}$ & $62.0^{\mathrm{dA}}$ \\
\hline & C. aucheri & $7.2^{\mathrm{e}}$ & $41.8^{\mathrm{ee}}$ & $68.8^{\mathrm{eC}}$ & $41.8^{\mathrm{eB}}$ & $11.2^{\mathrm{bbA}}$ & $56.3^{\mathrm{e}}$ & $1.7^{\mathrm{dA}}$ & $74.2^{\mathrm{ea}}$ \\
\hline & A. kenyensis & $3.1^{\mathrm{cD}}$ & $44.2^{\mathrm{ee}}$ & $63.7^{\mathrm{c}}$ & $33.7^{\mathrm{b}}$ & $11.3^{\mathrm{bbA}}$ & $54.5^{\mathrm{b}}$ & $1.9^{\mathrm{ccB}}$ & $80.3^{\mathrm{b}}$ \\
\hline & D. milanjiana & $5.0^{\mathrm{bA}}$ & $56.8^{\mathrm{b}}$ & $79.1^{\mathrm{b}}$ & $47.9^{\mathrm{a}}$ & $11.7^{\mathrm{abA}}$ & $44.7^{\mathrm{a}}$ & $1.5^{\mathrm{deA}}$ & $52.0^{\mathrm{a}}$ \\
\hline \multirow[t]{5}{*}{ Ds X OG } & C. roxburghiana & $6.8^{\mathrm{eB}}$ & $38.7^{\mathrm{ee}}$ & $59.3^{\mathrm{ee}}$ & $29.7^{\mathrm{e}}$ & $9.9^{\mathrm{bB}}$ & $58.8^{\mathrm{ee}}$ & $2.0^{\mathrm{adB}}$ & $91.2^{\mathrm{eb}}$ \\
\hline & C. ciliari & $11.4^{\mathrm{c}}$ & $46.5^{\mathrm{aB}}$ & $66.6^{\mathrm{c}}$ & $42.8^{\mathrm{cB}}$ & $14.0^{\mathrm{a}}$ & $52.7^{\mathrm{a}}$ & $1.8^{\mathrm{ecB}}$ & $73.5^{\mathrm{c}}$ \\
\hline & C. aucheri & $9.1^{\mathrm{dD}}$ & $39.4^{\text {dde }}$ & $59.4^{\text {be }}$ & $37.4^{\mathrm{dc}}$ & $13.1^{\mathrm{d}}$ & $58.2^{\mathrm{de}}$ & $2.0^{\mathrm{bdB}}$ & $90.2^{\mathrm{db}}$ \\
\hline & A. kenyensis & $4.4^{\mathrm{bC}}$ & $40.3^{\mathrm{cd}}$ & $61.1^{\mathrm{e}}$ & $26.6^{\mathrm{a}}$ & $11.9^{\mathrm{bA}}$ & $57.5^{\mathrm{c}}$ & $2.0^{\mathrm{bdB}}$ & $89.1^{\mathrm{a}}$ \\
\hline & D. milanjiana & $5.7^{\mathrm{aA}}$ & $51.4^{\mathrm{a}}$ & $72.3^{\mathrm{aA}}$ & $37.3^{\mathrm{bc}}$ & $13.3^{\mathrm{e}}$ & $48.9^{\mathrm{b}}$ & $1.7^{\mathrm{dcA}}$ & $64.4^{\mathrm{b}}$ \\
\hline
\end{tabular}

3 Note. Values in columns with different lower-case letters (a, b--etc) are significantly different $4 \quad(p<0.05)$ and values with the some second double lower case letters under the some treatment 
5 (aa, ba, cc, bc - etc) and values with both lower case and upper case letters across the treatment $6(\mathrm{aB}, \mathrm{abA}, \mathrm{acBD}-\mathrm{etc})$ are indicated not significant difference $(\mathrm{p}>0.05)$. GI = grazing intensity, 7 Ds = dry season, $\mathrm{Rs}=$ rainy season, $\mathrm{NG}=$ non- grazing, $\mathrm{MG}=$ moderate grazing, $\mathrm{OG}=$ over 8 grazing, $\mathrm{CP}=$ crude protein, $\mathrm{ADF}=$ acid detergent fiber, $\mathrm{NDF}=$ neutral detergent fiber, $\mathrm{ADL}=$ 9 acid detergent lignin, $\mathrm{DMD}=$ dry matter digestibility, $\mathrm{DMI}=$ dry matter intake $\mathrm{RFV}=$ relative 10 feed/forage value. 


\section{Table 4(on next page)}

Spearman's correlation coefficients of forage nutrient contents in the rainy and dry seasons at different $\mathrm{Gl}$

Rs $=$ rainy season, $\mathrm{Ds}=$ dry season 
1 TABLE 4 Spearman's correlation coefficients of forage nutrient contents in the rainy and dry

2 seasons at different GI

\begin{tabular}{|c|c|c|c|c|c|c|c|c|c|c|c|c|c|c|c|c|}
\hline \multicolumn{9}{|c|}{$\mathrm{RS}$} & \multicolumn{8}{|c|}{ Ds } \\
\hline & $\mathrm{CP}$ & $\mathrm{ADF}$ & NDF & $\mathrm{ADL}$ & Ash & DMD & DMI & RFV & CP & $\mathrm{ADF}$ & $\mathrm{NDF}$ & $\mathrm{ADL}$ & Ash & DMD & DMI & RFV \\
\hline $\mathrm{CP}$ & 1.00 & -.41 & -.46 & -.28 & .70 & .39 & .45 & .45 & 1.00 & -.37 & -.27 & .04 & .35 & .37 & .28 & .34 \\
\hline $\mathrm{ADF}$ & & 1.00 & .92 & .61 & -.54 & -.99 & -.86 & -.92 & & 1.00 & .87 & .01 & -.16 & -1.0 & -.88 & -.96 \\
\hline NDF & & & 1.00 & .64 & -.67 & -.91 & -.96 & -.97 & & & 1.00 & .04 & .01 & -.87 & -.98 & -.95 \\
\hline ADL & & & & 1.00 & -.46 & -.60 & -.67 & -.68 & & & & 1.00 & .07 & -.01 & -.13 & -.11 \\
\hline Ash & & & & & 1.00 & .53 & .72 & .69 & & & & & 1.00 & .16 & .06 & .11 \\
\hline DMD & & & & & & 1.00 & .85 & .91 & & & & & & 1.00 & .88 & .96 \\
\hline DMI & & & & & & & 1.00 & .99 & & & & & & & 1.00 & .97 \\
\hline RFV & & & & & & & & 1.00 & & & & & & & & 1.00 \\
\hline
\end{tabular}

3 Note. $\mathrm{Rs}=$ rainy season, Ds = dry season.

4 


\section{Table 5 (on next page)}

Spearman's correlation coefficients of forage nutrient contents at different GI

$N G=$ non-grazing, $M G=$ moderately grazing,$O G=$ over grazing 
1 TABLE 5 Spearman's correlation coefficients of forage nutrient contents at different GI

\begin{tabular}{|c|c|c|c|c|c|c|c|c|c|c|c|c|c|c|c|c|}
\hline \multicolumn{9}{|c|}{$\mathrm{NG}$} & \multicolumn{8}{|c|}{$\mathrm{MG}$} \\
\hline & $\mathrm{CP}$ & $\mathrm{AD}$ & ND & $\mathrm{AD}$ & Ash & $\mathrm{DM}$ & $\mathrm{DM}$ & $\mathrm{RF}$ & $\mathrm{CP}$ & $\mathrm{AD}$ & ND & $\mathrm{AD}$ & Ash & $\mathrm{DM}$ & $\mathrm{DM}$ & $\mathrm{RF}$ \\
\hline & & $\mathrm{F}$ & $\mathrm{F}$ & $\mathrm{L}$ & & $\mathrm{D}$ & I & $\mathrm{V}$ & & $\mathrm{F}$ & $\mathrm{F}$ & $\mathrm{L}$ & & D & I & $\mathrm{V}$ \\
\hline $\mathrm{CP}$ & 1.0 & .52 & .72 & .70 & .96 & -.53 & -.78 & -.70 & 1.0 & .44 & .66 & .46 & .96 & -.53 & -.76 & -.63 \\
\hline & 0 & & & & & & & & 0 & & & & & & & \\
\hline $\mathrm{ADF}$ & & 1.00 & .94 & .92 & .69 & -.99 & -.90 & -.96 & & 1.00 & .90 & .94 & .52 & -.95 & -.87 & -.95 \\
\hline $\mathrm{NDF}$ & & & 1.00 & .99 & .86 & -.95 & -.99 & -.99 & & & 1.00 & .95 & .75 & -.91 & -.99 & -.98 \\
\hline ADL & & & & 1.00 & .84 & -.93 & -.98 & -.99 & & & & 1.00 & .61 & -.86 & -.90 & -.95 \\
\hline Ash & & & & & 1.0 & -.70 & -.91 & -.85 & & & & & 1.0 & -.55 & -.82 & -.71 \\
\hline & & & & & 0 & & & & & & & & 0 & & & \\
\hline DM & & & & & & 1.00 & .91 & -.96 & & & & & & 1.00 & .91 & .96 \\
\hline D & & & & & & & & & & & & & & & & \\
\hline DMI & & & & & & & 1.00 & .99 & & & & & & & 1.00 & .97 \\
\hline RFV & & & & & & & & 1.00 & & & & & & & & 1.00 \\
\hline
\end{tabular}

2

\begin{tabular}{lllllllll}
\hline & \multicolumn{7}{c}{ OG } \\
\hline CP & CP & ADF & NDF & ADL & Ash & DMD & DMI & RFV \\
\cline { 2 - 8 } ADF & 1.00 & .39 & .40 & .60 & .91 & -.38 & -.58 & -.53 \\
NDF & & 1.00 & .98 & .94 & .68 & -.99 & -.85 & -.94 \\
ADL & & & 1.00 & .96 & .71 & -.97 & -.93 & -.99 \\
Ash & & & 1.00 & .83 & -.94 & -.95 & -.99 \\
DMD & & & & 1.00 & -.66 & -.84 & -.80 \\
DMI & & & & & 1.00 & .84 & .95 \\
RFV & & & & & & 1.00 & .97 \\
\end{tabular}

3

4 


\section{Table 6(on next page)}

Rotated component matrix for nutritional components of forage species data (Extraction method: Principal Component Analysis. Rotation method: Varimax with Kaiser Normalization) 
1 TABLE 6 Rotated component matrix for nutritional components of forage species data (Extraction 2 method: Principal Component Analysis. Rotation method: Varimax with Kaiser Normalization)

\begin{tabular}{ccccccc}
\hline \multirow{2}{*}{ Component } & \multicolumn{5}{c}{ Total Variance Explained } \\
\cline { 2 - 7 } & \multicolumn{2}{c}{ Extraction Sums of Squared Loadings } & \multicolumn{2}{c}{ Rotation Sums of Squared Loadings } \\
\cline { 2 - 7 } & \multicolumn{1}{l}{ Total } & \% of & Cumulative & Total & $\%$ of & Cumulative \\
1 & & Variance & $\%$ & & Variance & $\%$ \\
2 & 5.954 & 74.427 & 74.427 & 4.925 & 61.564 & 61.564 \\
& 1.011 & 12.641 & 87.067 & 2.040 & 25.503 & 87.067 \\
\hline
\end{tabular}

3

4 